Portland State University

PDXScholar

$1-1-1978$

\title{
Organizational decision making and participation in an interorganizational service network
}

Vinod Valji Chohan

Portland State University

Follow this and additional works at: https://pdxscholar.library.pdx.edu/open_access_etds Let us know how access to this document benefits you.

Recommended Citation

Chohan, Vinod Valji, "Organizational decision making and participation in an interorganizational service network" (1978). Dissertations and Theses. Paper 747.

https://doi.org/10.15760/etd.747

This Dissertation is brought to you for free and open access. It has been accepted for inclusion in Dissertations and Theses by an authorized administrator of PDXScholar. Please contact us if we can make this document more accessible: pdxscholar@pdx.edu. 


\title{
ORGANIZATIONAL DECISION MAKING AND PARTICIPATION \\ IN AN INTERORGANIZATIONAL SERVICE NETWORK
}

\author{
by \\ VINOD VALJI CHOHAN \\ A dissertation submitted in partial fulfillment \\ of the requirements for the degree of \\ DOCTOR OF PHILOSOPHY \\ in \\ URBAN STUDIES
}

Portland State University

1978 
TO THE OFFICE OF GRADUATE STUDIES AND RESEARCH:

The members of the Committee approve the dissertation of Vinod Valji Chohan presented August 1977.
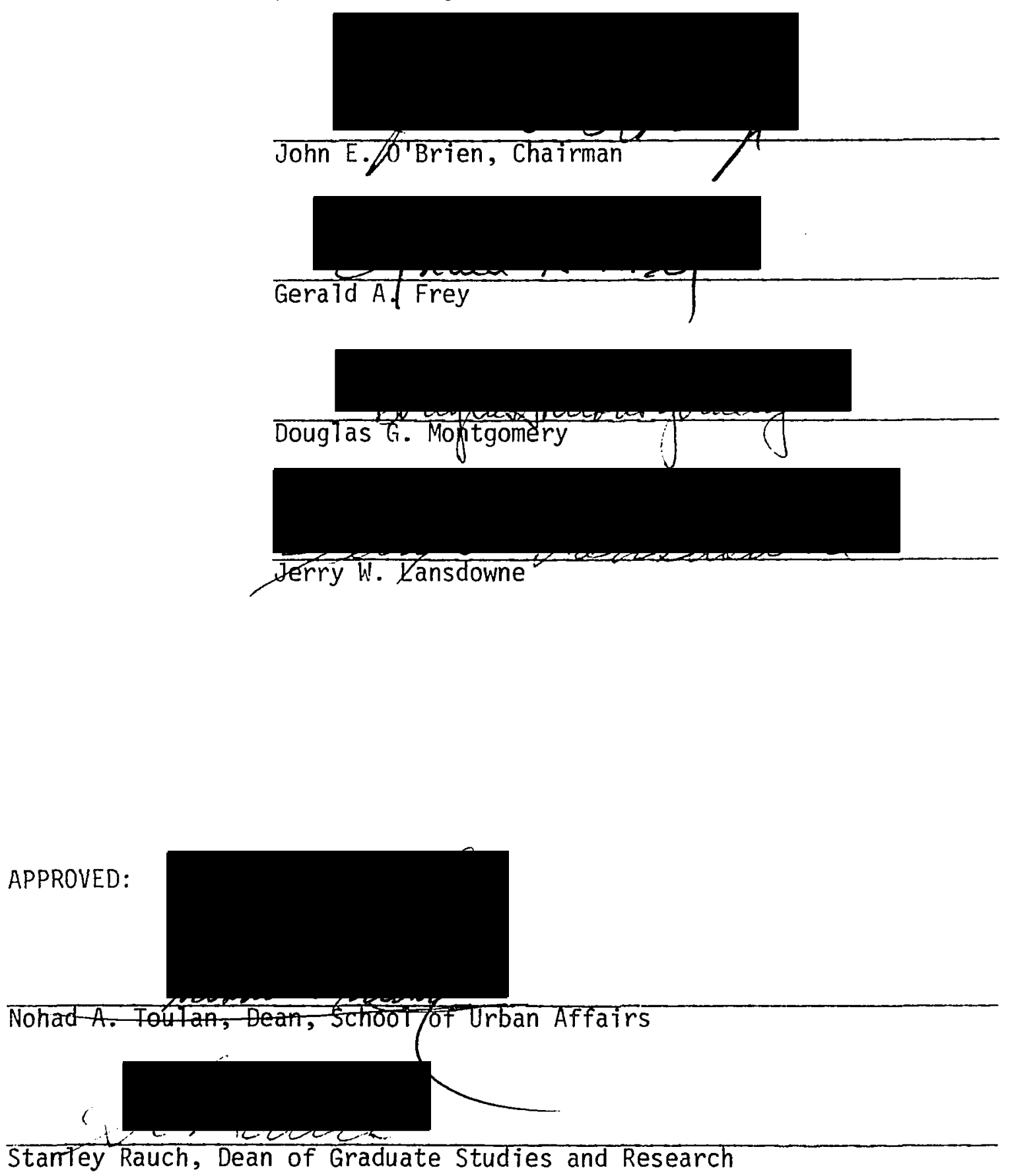
AN ABSTRACT OF THE DISSERTATION OF Vinod Valji Chohan for the Doctor of Philosophy in Urban Studies presented 1977.

Title: Organizational Decision Making and Participation in an Interorganizational Service Network

APPROVED BY THE MEMBERS OF THE DISSERTATION COMMITTEE:
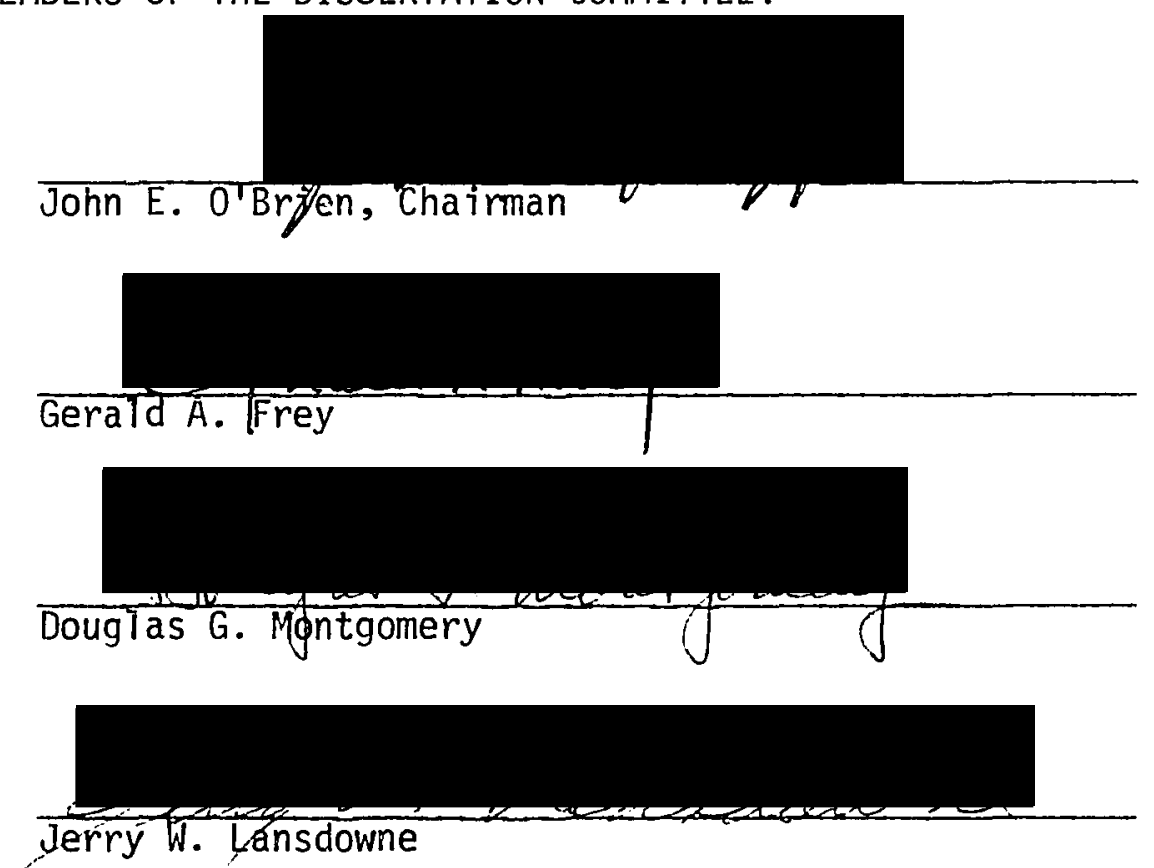

Scope of the Study

This study attempts to identify the variables associated with an organization's decision to participate in an interorganizational service network. The survev of literature on the subject supported the hypothesis that structural variables of complexity, formalization, and centralization and a psychological variable, the awareness of organiza- 
tional interdependency, are associated with the decision to participate. Interorganizational participation was operationally defined in terms of various behavioral components: an organization's involvement with the coordinating agency, client referrals to and from other organizations and to and from the coordinating agency, and information exchanged with other organizations and with the cosridinating agency.

Using this framework, testable hypotheses were formulated regarding the relationship between the selected measures of the independent variables of complexity, formalization, centralization, and awareness of interdependency and the dependent variable of interorganizational participation.

Human service agencies which provide services to the elderly in the State of Oregon were surveyed in this study. These agencies, together with the Area Agency on Aging, a coordinating agency established under the 0lder Americans Act, constituted the interorganizational service network. A main concern of that type of coordinating agency is to facilitate effective working relationships between the organizations in such service networks. This study was designed to explore the factors associated with that process.

Findings and Conclusions

The evidence presented suggests that the psychological variable of awareness of interdependency is significantly related to the decision to participate. This finding was generally supported by qualitative data gathered from six organizations examined under the case study method. 
For the structural variable it was found that: a) complexity was not significantly related to the decision to participate; b) centralization had a significant relationship with only some components of the measures of participation; c) there was some association between formalization and the participation processes.

In general, it appears that a key step to building effective networks of service organizations is to increase awareness of interdependency among organizational members. 


\section{ACKNOWLEDGMENTS}

This dissertation is the result of constant help and assistance which I received during the course of its preparation. It reflects the energy and dedication of numerous friends and colleagues, each of whom contributed in one form or another to its completion. It was my pleasure to work very closely with my conmittee chairman, Dr. John O'Brien, who patiently endured my weaknesses and reinforced my strengths. Without his encouragement and academic excellence in advising me this dissertation would not have been possible. The other committee members, Dr. Frey, Dr. Montgomery, and Dr. Lansdowne, as we11 as Dr. Shotola, offered continual support and encouragement, providing invaluable advice regarding the content and style of this document.

Members of the AAA-TA research team were very helpful in all phases of this research project. The principal investigators, Dr. Douglas Montgomery and Dr. Terrie Wetle, offered valuable advice and assistance. Special thanks are extended to my friend, Mr. Fred Keast, who read the manuscript and made constructive comments.

I thank the School of Urban Affairs and the Institute on Aging for financial and academic support during the preparation of this study.

Special mention should be made of Dr. Nohad Toulan, the Dean of the School of Urban Affairs, who gave continual guidance and advice during the preparation of this document.

Finally, my wife deserves a special vote of appreciation. She 
typed the document several times and shared in the trials and tribulations of its preparation. 
TABLE OF CONTENTS

PAGE

ACKNOINLEGMENTS ...............................

LIST OF TABLES .......................... ix

CHAPTER

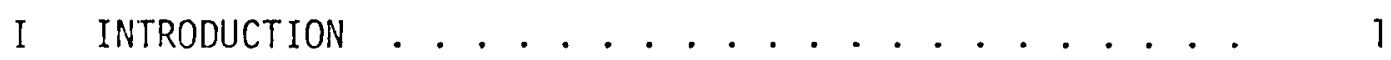

Introduction ................ 1

Statement of the Problem ......... 5

Purposes of the Study ........... . . 7

Research Questions ......... . 7

Assumptions ................ 7

Limitations .................. 8

Definition of Terms ........... 8

II REVIEW OF LITERATURE . . . . . . . . . . . . 13

Introduction ............ 13

The Structure of Bureaucracy . . . . . . 15

Factors That Limit Participation . . . . . . 17

Factors That Facilitate Participation . . . . 19

Mechanistic Model .......... 20

Organic Mode1 ............ 21

Profile of Selected Independent Variables . . . . 22

Profile of Organizational Complexity . . . . 22 
Profile of Organizational Formalization . . . 25

Profile of Organizational Centralization . . . 26

Profile of Awareness of Interdependency . . . 27

Relationship Between the Selected Variables

and Participation............ . . 30

Conceptualization of the Thesis . . . . . . 32

Decisions Involving Change ......... . . 33

Summary . . . . . . . . . . . . . 35

II METHODOLOGY AND DESIGN ............... 37

Population and Sample............ 37

Collection and Processing of Quantitative Data . . 37

Collection and Processing of the

Qualitative Data ............ 39

Statement of Hypotheses........... . . 40 40

Statisticat Design ............ 40

IV ANALYSIS OF THE DATA ............. . . . 42

Introduction .............. . . . 42

Analysis of the Relationship Between Measures

of the Independent Variables Using

Zero-Order Correlation .......... . . 42

Analysis of the Relationship Between Measures

of the Dependent Variable Using

Zero-Order Correlation ...........

Statistical Analyses of the Relationships Between the Independent Variables and Measures

of the Dependent Variable .......... . 50

Analysis of the Relationships Between the

Independent Variables and Measures of

the Dependent Variable Using

Zero-Order Correlation . . . . . . . . . 
Analysis of the Relationships Between the Independent Variables and Measures of the Dependent Variable Using Multiple

Regression Analysis . . . . . . . . . . . .

Analysis of the Relationships Between the Independent Variables and Measures of the Dependent Variable While Controlling Selected Components of the Independent Variables . . . . . . . . .

Analysis of the Variance in Measures of the Dependent Variables Explained by the Independent Variables......... . 65

Discussion of the Findings . . . . . . . 67

Quailitative Case Analysis of the Relationships

Between the Independent Variables and of the Dependent Variable . . . . . . . . 72

Analysis of the Case Studies . . . . . . 72

Discussion of the Findings . . . . . . . 87

$\checkmark$ SUMMARY, CONCLUSIONS, IMPLICATIONS

AND RECOMMENDATIONS ................... . . . 89

Introduction . . . . . . . . . . . . 89

Summary of the Findings ............ . 91

Conclusions . . . . . . . . . . . . . 93

Implications . . . . . . . . . . . 94

Implications for Research . . . . . . . 94

Implications for Practice . . . . . . . 95

Recommendations for Further Research . . . . . 96

A SELECTED BIBLIOGRAPHY . . . . . . . . . . . . . . 100 


\section{APPENDICES}

A QUESTIONNAIRE FOR COLLECTING DATA ON COMPLEXITY, FORMAL IZATION, CENTRALIZATION, AWARENESS OF

INTERDEPENDENCY AND DECISION TO

PARTICIPATE ................... 174

B FRAMEWORK FOR CASE STUDIES INTERVIEWS . . . . . . 119 
TABLE

PAGE

I SAMPLE OF THE STUDY . . . . . . . . . . . . . 38

I I RELATIONSHIP BETWEEN MEASURES OF INDEPENDENT VARIABLES • 44

III RELATIONSHIP BETWEEN MEASURES OF DEPENDENT VARIABLE . . . 47

IV RELATIONSHIP BETWEEN INDEPENDENT VARIABLES

AND MEASURES OF DEPENDENT VARIABLE . . . . . . . . . 51

$\checkmark$ MULTIPLE REGRESSION MATRIX: RELATIONSHIP BETWEEN INDEPENDENT VARIABLES AND DEPENDENT VARIABLE . . . . . . 55

VI PARTIAL CORRELATION COEFFICIENTS BETWEEN MEASURES OF DEPENDENT VARIABLE AND EACH INDEPENDENT VARIABLE, WHILE CONTROLLING OTHER INDEPENDENT VARIABLES . . . . . . 58

VII VARIANCE IN DEPENDENT VARIABLE EXPLAINED BY A SET OF INDEPENDENT VARIABLES . . . . . . . . . . . . . 66 


\section{CHAPTER I}

\section{INTRODUCTION TO THE PROBLEM}

It is my central thesis that empirical research goes far beyond the passive role of verifying and testing theory: it does more than confirm or refute hypotheses. Research plays an active role: it performs at least four major functions which help shape the development of theory. It initiates, it reformulates, it deflects and it clarifies theory (Rovert Merton, 1957).

\section{INTRODUCTION}

With the proliferation of organizations in modern urban communities, the issue of interagency participation in coordinated social service networks has generated a new interest in the field of organization theory and research. In the last few decades numerous social service organizations have emerged to meet the complex needs of urban society. These organizations provide services which are often specialjzed and, unfortunately, do not address human needs resulting from interconnected problems. Organizational mechanisms for service delivery in the form of semiautonomous agencies are usually ineffective and inefficient in addressing needs that cut across problem areas, geography, and income (Aram et a., 1973 ). To be effective, organizations must be brought together to provide a continuum of care and a fixed point of referral within a coordinated system (Hage, 1971).

The question is, in what way can one bring these organizations together so that they provide a continuum of care within a coordinated 
delivery system? This raises the issue of interorganizational participation and cooperation. What are the processes and parameters of interorganizational participation in a social service network? The answers to these questions are not readily available because the study of interagency participation is in an initial stage of development. As a social science, organization theory is strongly influenced by classic economic theory which argues against interagency cooperation. The economic model postulates interagency competition as the optimal solution for the problem of organizational effectiveness and efficiency. This economic argument highlights the distinction between "product processing" organizations versus "people processing" organizations. The classic economic model of competition is designed for "product processing" organizations whose principal goal is to maximize profit. Social service organizations are not established to make profit. Their sine qua non is to provide a social service to meet the complex needs of modern man. Because these needs are interconnected and interrelated, service organizations should provide a continuum of care within a coordinated delivery system. Therefore, cooperation and not competition is an ideal model for "people processing" organizations (0'Brien \& Wetle, 1976).

If interagency cooperation is a solution to the problem of fragmented and ineffective social service delivery systems, what are the factors influencing interagency participation in a social service network? In what ways can interagency participation in a service network be promoted? In the past few years a new multidisciplinary approach to the study of interorganizational analysis has emerged. 
This approach is based on principles derived from organizational sociology, psychology, economics, social psychology, and pubtic administration. In this field researchers have studied the processes and parameters of interorganizational relations and participation using a multidisciplinary approach. Roland Warren (1972) has analyzed interagency relations within the context of what he calls "organizational interaction." Levine and White (1961) have explained interagency relations in terms of exchange theory. O'Brien and Wetle (1975) have theorized that interagency participation is associated with the processes of conflict and coordination. Thompson and McEven (1958) have explained interorganizational relations in terms of an organizational goal-setting process.

Before an organization interacts with another organization it has to make a decision to interact or not to interact. Before an organization participates in exchange processes it has to decide whether it wants to participate in such exchange transactions. Organizational goal-setting is described by Thompson and McEven (1958) as a decision making process. Decision making is a critical element in interorganizational relations. Analysis of this element may reveal the essential elements of interagency participation.

The decision to participate in a service network or to cooperate in coordinating services with other agencies should not be viewed as an ordinary or routine decision. To participate or coordinate involves some changes on the part of the participating agency; that is, internal adjustments are needed when an agency decides to coordinate its services with other agencies. Therefore, a decision to participate in a 
service network is a decision involving organizational change. March and Simon (1958) refer to such decisions as "non-programmed" or "nonroutine" decisions. To study the decision to participate is to study the processes of organizational change. Therefore, interagency participation in a service network has a frame of reference in the conceptual and theoretical framework of organizational change literature. Decision making, whether individual or organizational, is still in the process of theoretical and empirical development. In defining decision making, it is more appropriate to think in terms of patterns and models rather than a paradigm. There are two distinctive approaches to decision making: one may be described as a structuralfunctional perspective and the other as a social-psychological perspective. The structural-functional perspective views decision making as associated with the structural properties of the organization. The presence or absence of certain structural properties may result in certain types of decisions. The social-psychological perspective considers decision making as a process involving various strategies employed by organizations in response to a variety of situations.

The structural-functional perspective is advanced by Burns and Sta7ker (1961), Hage and Aiken (1967, 1970), and Hage (1971). Burns and Stalker (1961) have advanced the theory that there are two types of organizational systems, mechanistic and organic. The mechanistic system is rigid, production-oriented, and highly formalized. The organic system is flexible, people-oriented, adaptive, and innovative. Adopting this model of organizational systems, Hage and Aiken (1970) 
have formulated a theory of organizational change based on the internal structure of organizations. The internal structure of the mechanistic system consists of variables of low complexity, high centralization, high formalization, high stratification, low adaptiveness, high production, high efficiency, and low job satisfaction. Such a structure does not accommodate innovation or change easily. The internal properties of the organic system are high complexity, low centralization, low formalization, low stratifications, high adaptiveness, low production, low efficiency, and high job satisfaction. One of the implications of these models is that an organization with an organic system is likely to accommodate change more easily than the organization with the mechanistic system.

\section{STATEMENT OF THE PROBLEM}

In the State of Oregon there is an informal network of service providers which deals with the problems of older people. An agency called the Area Agency on Aging was funded by the federal government to coordinate this informal network. The Area Agency on Aging is the coordinating agency in this study. The coordinating agency has attempted to create a network of alliances among service providers to facilitate provision of comprehensive service to the elderly in each community. Efforts of the coordinating agency have been met with continued resistance by the service providers.

If one assumes that the decision to participate in a service network is a decision involving organizational change, then the structural characteristics of such a decision can be studied. Hage (1965) 
has argued that organizational characteristics of complexity, formalization and centralization are associated with decisions to change. In more specific terms, Hage (1965) has hypothesized that organizational change is associated with high complexity, low formalization, and high centralization.

The social-psychological perspective views decision making as a social-psychological process. This process is largely determined by the nature of the problem and external influences on the decision making process. Most social psychologists do not accept the structural-functional view of the decision making process. They argue that elements of the structural-functional perspective such as the degree of centralization and the degree of complexity become, if not ultimately reducible, at least secondary to psychological factors.

In their studies of organizational change Hage and Aiken (1967) examine this argument by measuring and analyzing several personality variables. They found that personality characteristics added little to understanding of organizational change. Recently, theoreticians have developed a new concept which seeks to explain the psychological dimensions of an organization's decision to participate in an interorganizational service network. Matthew Tuite (1972) refers to this concept as the organization's "recognition of interdependency" with other agencies. Litwak and Hylton (1962) call it the "self-awareness of interdependency." Hage (1971) calls it "organizational interdependence." The principal argument behind this concept is that cooperation or coordination between organizations will not take place unless there exists an organizational awareness of the interdependency of coordinating and 
cooperating agencies.

\section{PURPOSES OF THE STUDY}

The purposes of this study are:

1. to examine the relationships between selected variables among organizations providing services to the elderiy and their decision to participate in an interorganizational network;

2. to ascertain the relative contribution of these selected variables to the organization's decision to participate in an interorganizational network.

\section{RESEARCH QUESTIONS}

This study is designed to answer the following questions:

7. Is there a significant relationship between selected variables among organizations providing services to the elderly and their decision to participate in an interorganizational network?

2. What is the relative contribution of the selected variables to the decision to participate in an interorganizational network?

\section{ASSUMPTIONS}

1. The organizations in this study are representative of service providers in the State of Oregon.

2. The instruments and techniques used in this study are valid and reliable only in so far as the organizations in this study are willing to participate. 


\section{LIMITATIONS}

1. This study is Timited to organizations providing services to the elderly in the State of Oregon. Because of the nature of the sample, it may not be feasible to generalize to other service providing organizations.

2. This study is also limited by human difference in response to questionnaires and interviews and by possible human error in record keeping and transcription of data.

3. A final imitation has resulted from the nature of the data gathering. Although the incerview technique and the questionnaire were tested in advance of the study, a possibility exists that the interviews and the questionnaire failed to reveal significant information adequately. Although not aware of such defects in the interview technique and questionnaire, the researcher feels it is necessary to state that if defects exist they would influence the findings.

\section{DEFINITION OF TERMS}

A. Selected independent variables: The following variables have been selected as the independent variables in this study: the complexity of an organization; the decision making process of an organization; and an organization's awareness of interdependency.

Components of the selected variables are:

1. complexity

a. as indicated by organization size

b. as indicated by levels of authority within the organization 
2. centralization

a. as indicated by the extent to which staff participates in service decisions. Service decisions involve provision and administration of services.

b. as indicated by the extent to which staff participates in program decisions. Program decisions involve the establishment and development of new programs.

3. formalization

a. as indicated by the extent to which jobs are codified

b. as indicated by the extent to which staff members are required to go through hierarchical channels

4. awareness of interdependence

a. as indicated by the extent to which an organization perceives a need for community support to achieve objectives

b. as indicated by the extent to which an organization perceives the interrelatedness of their own programs with those of other agencies

B. Dependent variable: The dependent variable of this study is an organization's decision to participate in an interorganizational service network. The eight components selected as indicators of the decision to participate are:

1. frequency of involvement which the organization has with the coordinating agency

2. number of client referrals by the organization to other 
agencies

3. number of client referrals from other agencies to the organization

4. number of client referrals from the organization to the coordinating agency

5. number of client referrals from the coordinating agency to the organization

6. number of times information was provided to other agencies by the organization

7. number of times information was provided by the organization to the coordinating agency

8. number of times information was provided by the coordinating agency to the organization.

C. The coordinating agency: The Area Agency on Aging was funded by the Department of Health, Education, and lelfare, under the 01der Americans Act, to coordinate activities of agencies providing social services to the elderly.

D. The interorganizational service network: A network is formed when a number of organizations engage in extensive interaction. This interaction should be for the purpose of cooperation and not for the purpose of competition.

E. The service providers: The service providers are the social service agencies providing services to the senior citizens in the State of Oregon.

F. Aging service network: An informal network of service providers in the State of Oregon. 
G. The 01der Americans Act: The 01der Americans Act of 1965, as amended in 1973. Implementation of provisions of this Act resulted in the establishment of more than 500 Area Agencies on Aging (AAA) throughout the United States of America with the responsibility of facilitating the development of a comprehensive coordinated system of services.

H. Levels of participation (involvement):

1. High level of participation: Organizations that indicated involvement on five or more of the components of the dependent variable were considered highly involved.

2. Moderate level of participation: Organizations which indicated involvement on three or four of the components of the dependent variable were considered moderately involved.

3. Low level of participation: Organizations which indicated involvement on two or less of the components of the dependent variable were considered to have a low Tevel of involvement.

I. Organizational values: The following organizational values were utilized in this study and are defined as:

1. Autonomy: the ability of an organization to be independent and self-governing.

2. Power: the ability of an organization to exercise control over other organizations.

3. Status: the ability of an organization to maintain or increase its prestige or "image" in the community. 
4. Domain: the ability of an organization to maintain commonly held boundaries of operation such as purpose, type of client, and geographical area (0'Brien and Wetle, 1975). 


\section{CHAPTER II}

\section{REVIEW OF THE LITERATURE}

The passion for bureaucracy is enough to drive one to despair. It is as if in politics we were deliberately to become men who need 'order' and nothing but order, who become nervous and cowardly if for one moment this order wavers, and helpless if they are torn away from their total incorporation in it. That the world should know no men but these: it is such an evolution that we are already caught up in, and the great question is therefore not how we can promote and hasten it, but what can we oppose to this machinery in order to keep a portion of mankind free from this parceling-out of the soul from this supreme mastery of the bureaucratic way of 1 ife (Max Weber, 1956).

\section{INTRODUCTION}

A high degree of urbanization has caused the modern urban community to become a community of organizations. As Amitai Etzioni (1964) indicated, organizations take care of people from birth to death. Probably the most distinctive feature of modern urban society is that we increasingly rely on organizations to solve our problems. Whether it is a housing problem or a problem of poverty, organizations are created to solve these problems. As Roland Warren (1963) stated, most functions which were traditionally handled by the family are now being taken over by social service agencies. For instance, parental guidance has been transferred in part to such agency professionals as guidance counselors, teachers, and school psychiatrists. Similarly, provision by the family for old age dependency has been largely taken over by the government through the Social Security system. In brief, organizations 
have become a most powerful vehicle for implementing social and urban policies.

The creation, promotion, and establishment of organizations to meet complex human needs has created a problem of interorganizational cooperation and coordination. This is because social service agencies are "people processing" organizations and are different from "product processing" organizations. The ideal model for "product processing" organizations is competition to enhance efficiency and to maximize profit. But the ideal model for "people processing" organizations is cooperation for the purpose of creating a coordinated delivery system to provide a continuum of care. The structural and administrative processes of service organizations are not essentialiy different from product processing organizations, as both types of organizations are indeleci on the principles of Weberian bureaucracy. This may mean that the bureaucratic structure of participating agencies influences interagency participation. One needs to review the ideal model of bureaucracy as formulated by Max Weber to help understand the processes and parameters of interagency participation in a service network. At the same time one needs to identify the unintended consequences of certain bureaucraiic principles for the organization's ability to change or to maintain status quo. In brief: one needs to identify the built-in structural properties of bureaucratic organizations which enhance or hinder the processes of organizational change that may lead to participation in an interorganizational service network. 
THE STRICTURE OF BUREAUCRACY

Max Weber, who was born in Germany in 1864 and died in 1920, wrote extensively on bureaucracy. Weber pioneered the theory of bureaucracy and wrote many seminal volumes on this subject. Weber (1947) begins his discussion of bureaucracy with three types of legitimate authority: rational-legal authority, traditional authority, and charismatic authority. According to Weber (1947), rational-legal authority claims legitimacy under a belief in the "legality" of patterns of normative rules and the right to issue commands of those elevated to authority under such rules. Traditional authority claims legitimacy under an established belief in the sanctity of immemorial traditions and the legitimacy of the status of those exercising authority under those traditions. Charismatic authority bases its legitimacy on the idea of devotion to the specific and exceptional sanctity, heroism or exemplary character of an individual person and of the normative patterns of order revealed or ordained by him (Weber, 1947).

Weber (1947) argued that among the three types of authority, the rational-legal type was becoming prominent because it had characteristics which promoted organizational effectiveness and efficiency. He discussed the salient characteristics of the rational-legal type in the following terms:

1. There is the principle of official jurisdictional areas which are generally governed by rules. Regular duties are assigned as official duties and authority to discharge these duties is rationally distributed. Procedures are provided for the regular and continuous fulfillment of these duties. 
2. Positions or offices are organized into a hierarchical structure. A system of supervision of the lower office by the higher office is clearly established.

3. The office is based upon written documents called "files" which are preserved in their original form. The officers and the files make up a bureau.

4. Management of the office presupposes that the employee has a thorough training in his field of specialization.

5. The position of an official in a bureau demands full working capacity of that official.

6. Formal rules of the office are fairly stable and can be learned. Officials are required to have knowledge of these rules which represents a special technical expertise.

7. An office is a "vocation." It requires a special course of training as a prerequisite for occupying the office.

8. Unlike an elected official, the bureaucratic official is appointed by a superior authority.

9. In a bureaucracy, the position of the official is held for 1ife. As a rule, tenure for 1 ife is assumed even where notice of termination can be given.

10. The official, as a rule, receives a monetary compensation in the form of a salary.

11. In a bureaucracy, the official expects to move from a lower, less important and less well paid position to a higher position.

According to Bendix (1968), Weber was describing an ideal type of bureaucracy and not one which existed during his time. 
FACTORS THAT LIMIT PARTICIPATION

Observation indicates that modern organizations tend to adopt Weberian principles of organization to become more effective and efficient in achieving their goals. Unfortunately, the bureaucratic structure has unintended consequences which affect an organization's ability to respond to a changing environment. Robert Merton (1957) has articulated these unintended consequences of bureaucratic structures. He refers to them as the "dysfunctions" of bureaucracy. Merton contends that Weber, in describing bureaucratic organizations, emphasizes their positive attainments and functions while ignoring the internal stresses and strains of such structures which are the negative aspects of bureaucracy. Merton argues that the most serious dysfunction is resistance to change, fostered by overconformity to rules.

This overconformity is the outcome of constant pressure to be methodical, prudent and disciplined and is exerted by the bureaucratic structure upon the official. Emphasis on adherence to organizational rules, originally conceived as a means, becomes transformed into an end. When this happens there occurs the familiar process of displacement of goals, whereby an instrumental value becomes a terminal value. The transformation of an instrumental value into a terminal value leads to overconformity and rigidity.

Merton calls this overconformity and rigidity "trained incapacity." He defines trained incapacity as that state of affairs in which one's abilities function as inadequacies or blind spots. According to Merton, there are four structural sources of this trained incapacity:

(a) An effective bureaucracy demands reliability of response and 
strict devotion to regulations. (b) Such devotion leads to transformation of the rules into absolutes; they no longer are conceived as relative to a set of purposes. (c) This transformation interferes with ready adaptation to future conditions not clearly envisaged by those who draw up the general rules. (d) Thus, the elemerits which are generally conducive to efficiency produce inefficiency in specific instances (Merton, 1957). Merton's principal argument is that each manifest function in a bureaucracy has latent consequences which make it difficult for this structured organization to change.

Robert Merton emphasizes the dysfunctionality of bureaucratic organizations to change. The history of organizations suggests that they do adapt to changing conditions. Organizations which did not adapt to changing conditions did not survive. The question is, why do some organizations survive while others perish? To understand this riddle, one needs to study the processes of organizational change. At the present time, the study of organizational change is in its initial stage of development. Social scientists are still searching for answers to the questions of how and why organizations change, what are the processes and variables of organizational change, and what are methods for introducing planned change in the organization.

In surveying the literature, this researcher found that various theories and models have been advanced to explain organizational change. These theories and models can be broadly divided into two categories: those that explain organizational change in terms of external environmental factors, and those that explain organizational change in terms of internal organizational factors such as complexity, centralization, 
formalization, elite values, and leadership styles. These theories represent the famous debate of environment versus heredity. This study is not intended to discuss this debate, but rather is designed to study the internal characteristics of an organization which have a bearing on organizational change. It is assumed that although two or more organizations may have the same environment, some may change while others maintain the status quo. It is expected that this difference between changing and unchanging organizations may be accounted for by the internal structure of these organizations.

\section{FACTORS THAT FACILITATE PARTICIPATION}

In the literature on organizational change, there is support for the contention that there are various types of organizational structures. Some structures are more conducive to change than others. The concept of types of organizational structures has been discussed at some length by Burns and Stalker and Aiken and Hage. According to Burns and Stalker (1961), there are two types of organizational systems: mechanistic and organic. Though the authors did not argue in favor of any one system, Aiken and Hage (1971) have demonstrated that the organic model is more amenable to change and thus most conducive to innovation. They adopt Victor Thompson's (1965) definition of innovation as the "generation, acceptance and implementation of new ideas, processes, products or services for the first time within an organizational setting." When innovation is viewed in this sense, the first problem is to identify those organizational characteristics that facilitate or retard innovation in an organization. According to Aiken 
and Hage (1971), the organic model of organization facilitates innovation in an organization.

\section{Mechanistic Model}

The mechanistic model was formulated by Burns and Stalker (1961). They contend that the mechanistic model is a result of Weber's model of bureaucracy and is appropriate under stable conditions. The distinguishing characteristics of the mechanistic model are:

1. The specialized differentiation of functional tasks

2. The abstract nature of each individual task, which is pursued with techniques and purposes more or less distinct from those of the concern as a whole

3. The precise definition of rights and obligations; technical methods are attached to each functional role

4. The translation of rights, obligations, and methods into the respensibilities of a functional position

5. Hierarchic structure of control, authority and communication

6. Reinforcement of the hierarchic structure by location of knowledge at the top of the hierarchy

7. A tendency for interaction between members of the firm to be vertical (i.e., between superior and subordinate)

8. A tendency for operations and working behavior to be governed by instructions and decisions issued by superiors

9. Insistence on loyalty to the firm and obedience to superiors as a condition of membership

10. Greater importance and prestige attaching to internal knowledge, experience and skill. 
According to Jerald Hage (1965), the mechanistic model can be described in terms of low complexity, high centralization, high formalization, high stratification, low adaptiveness, high production, high efficiency, and low job satisfaction.

Burns and Stalker (1961) contend that the mechanistic model is more appropriate for stable conditions, while the organic model is more appropriate to changing conditions.

Organic Model

Aiken and Hage (1971) utilized Burns and Stalkers' conception of the organic model of organizations to abstract some key variables of organizational change. Their formulation is as follows:

Characteristics

1. Contributive nature of special knowledge and experience

2. Adjustment and continual redefinition of individual tasks

3. Network structure of control, authority and communications

4. Lateral rather than vertical communication

5. Importance and prestige attached to affiliations and expertise $\underline{\text { Variables }}$

1. Degree of complexity

2. Degree of formalization

3. a. Degree of centralization

b. Intensity of scheduled communication

4. Intensity of unscheduled communication between departments

5. a. Degree of professional training

b. Degree of professional activity 
According to Hage and Aiken (1971), the organic organizational structure provides a basis for developing a theory of organizational change. They have advanced the sociological argument that organizational change is associated with the structural variables of complexity, centralization and formalization. Aiken and Hage (1968) empirically tested the relationship between organizational change and structural properties of complexity, formalization, and centralization. They equated organizational change with the rate of program change.

To understand why the structural variables of complexity, centralization and formalization are associated with organizational change it is necessary to examine the variables more closely.

\section{PROFILE OF SELECTED INDEPENDENT VARIABLES}

Profile of Organizational Complexity

In organizational literature there is an unsettled controversy about the relationship between size and organizational complexity. It is argued by some scholars that the size of an organization somehow "makes a difference" in other structural characteristics. Caplow (1957) and Grusky (1961) have argued that large organizations are, by definition, more complex and formalized than small organizations. Blau and Scott (1962) have argued to the contrary. Empirical studies using size as a major variable have not settled the issue. Studies by Chaplin (1951) and Tsouderas (1955) have indicated that size is related to an increased degree of bureaucratization. An empirical study by Hal1 (1963) has demonstrated that size is not a major factor in determining the degree of bureaucratization in an organization. Commenting 
on these contradictory findings, Hall et al. (1967) have contended that any assumption about size must be systematicaliy investigated before size can be taken as an indicator of organizational complexity. There is another dimension apart from size which may be of interest in determining complexity of an organization. This dimension is the relationship between size and the administrative component of organizations. Empirical studies by Terrien and Mills (1958) have demonstrated that the administrative component increases disproportionately as organizational size increases. However, this finding is not supported by Anderson and Workov (1961) who found that larger organizations contained a smaller proportion of personnel engaged in administration. Recent studies by Hawley et al. (1965) and Haas et al. (1963) have suggested that this relationship may be curvilinear, with the administrative component at first increasing disproportionately in size and then decreasing with further organizational growth. In summary, size can be taken as one indicator of complexity but not the sole indicator. In this study, size is treated as one of the indicators of complexity. The total number of paid employees in an organization is taken as a measure of size. Hall et al. (1967) used the same method for measuring size in their studies.

Hage (1965) has attempted to operationalize complexity, suggesting that complexity can be measured in terms of the number of occupational specjalties and the length of training required by each. The greater the number of occupations and the longer the period of training required, the more complex the organization. This definition emphasizes only one aspect of complexity, that of specialization. A broader 
view of complexity is offered by Pugh et al. (1963). While the term they use is "configuration," their meaning is closer to the more general issue of structural complexity. They have argued that every organization has an authority structure. The shape or configuration of this structure may be compared in different organizations. Components of this configuration are vertical and lateral span of control, criteria for segmentation, and the number of positions in various segments. These authors also suggested that size is apt to be a major determining factor of organizational structure.

The concept of complexity as formulated by Pugh et a1. (1963) is reinforced by Kahn et al. (1964), who suggest that with increased size, the structure of an organization becomes much more complex. Division of labor becomes more differentiated and specialized; more levels of supervision are introduced to maintain coordination and control; and more people become involved in organizational planning.

Summarizing the main empirical findings on the issue of complexity, Hall et al. (1967) conclude that complexity is a structural condition which contains a number of components. They define complexity in terms of degree of internal segmentation. Internal segmentation consists of division of labor, number of hierarchical levels, and spatial dispersion of the organization.

In summary, two factors appear to be key indicators of complexity: size and internal segmentation. Therefore, in this study the size and number of levels of authority (an indicator of internal segmentation) have been taken as indicators of organizational complexity. 
Profile of Organizational Formalization

The concept of organizational formalization has been explicitly defined and utilized. Hage (1965) has defined formalization as the proportion of jobs that are codified by position and range of variation allowed within jobs. Aiken and Hage (1968) have suggested that formalization is measured by the proportion of codified jobs and the range of variation that is tolerated within rules defining the jobs. The higher the proportion of codified jobs and the less the range of variation allowed, the more formalized the organization. Pugh et al. (1963) have equated formalization with standardization. According to them, standardization consists of procedures, rules and roles. Hall et al. (1967) have amplified the concept of formalization as formulated by Pugh et a1. (1963) and have defined formalization in terms of five components: (1) roles, (2) authority relations, (3) communications, (4) norms and sanctions, and (5) procedures.

Important dimensions of formalization are the rules or regulations which are used as organizational mechanisms to insure the predictability of performance. As argued by Hage and Aiken (i967), there are two aspects of the use of rules as a mechanism of social control. One is the number of regulations specifying who is to do what, where, and when (this is called the degree of job codification). Another is the diligence in enforcing the rules that specify who is doing what, where, and when (this is called rule observation).

In this study, formalization is defined in terms of job codification and rule observation. Job codification measures the degree to which the positions in an organization are concretely defined; rule 
observation measures the degree of emphasis placed on going through established channels in the communication process.

\section{Profile of Organizational Centralization}

Centralization is the degree to which power is concentrated in a social system (Aiken and Hage, 1966). In an organization, for example, the maximal centralization would exist if all the power was exercised by a single individual. Conversely, the minimum degree of centralization would exist if power was exercised equally by all members of the organizaition.

Hage (1965) defines centralization as the proportion of staff members included in decision making and the number of areas in which decisions are made. Hage (1965) hypothesized that centralization is positively related to formalization, stratification, production, and efficiency but negatively related to complexity, adaptativeness, and job satisfaction. This hypothes is was confirmed to some extent by Hall (1963). To measure several dimensions of Weber's model, Hall developed a series of scales which he called hierarchy of authority, division of labor, system of rules, and system of procedures. He found that hierarchy of authority had a high correlation with a system of rules and procedures and a lower correlation with division of labor, which in turn had almost no correlation with the use of rules. Hall found centralization and formalization were highly correlated.

In organizational literature, there is a growing debate about the relative merits of centralization as opposed to decentralization in decision making. Weber (1947) has argued that strict hierarchy of authority increases both the volume of production and the efficiency of 
an organization. Human relations specialists like Coch and French (1948) have argued that decentralization increases job satisfaction and reduces resistance to change. The debate is far from settled.

\section{Profile of Awareness of Interdependency}

Besides organizational characteristics of complexity, formalization and centralization, an organization's perception of its relationship to other organizations is an important element in establishing interorganizationai linkages. This perception is a psychological element of interagency participation. Organizational scholars have discussed this aspect of interagency linkages. Matthew Tuite (1972) has called it the organization's "recognition of interdependency;" and Hage (1971) has called it "organizational interdependence." The concept of organizational awareness of interdependence is discussed in some depth by Litwak (1970). According to Litwak, organizational awareness of interdependence is the minimum condition for any form of 1inkage. By interdependence, Litwak means two or more organizations must utilize each other to best achieve their individual goals.

If interdependence is defined in this way, it raises the question, what states of interdependence provide the bases for linkages between two or more organizations? Litwak (1970) has hypothesized that partial interdependence is the ideal basis for maintaining a confederation of organizations. Justifying his hypothes is on a conceptual basis, Litwak (1970) has argued that where there are complete states of interdependence between two more more organizations, the ideal solution would be an organizational merger or the destruction of all but one organization. In such cases, there would be no need for interorganiza- 
tional linkages as the problem would become intraorganizational. On the other hand, if two or more organizations had no interdependence at a11, the ideal solution would be no linkage.

Amplifying his concept of partial interdependence, Litwak (1970) points out that partial interdependence includes the concept of reciprocity or symmetrical exchanges. Litwak (1970) hypothesizes that in cases of extreme asymmetry in interdependence, there will be no linkage or there will be complete merger depending on the inclination of the non-dependent members. In summary, Litwak advances the theory that partial interdependence is crucial to linkages between organizations. Complete interdependence and complete dependence tend to lead away from interorganizational linkages. Therefore, partial states of interdependence are minimum conditions for the discussion of a11 linkage mechanisms.

Partial states of interdependence will not alone tell us what form interorganizational linkages will take. Organizations must be aware of interdependence. By organizational awareness, Litwak (1970) means that an organization must publicly recognize its interdependence with another organization. In its extreme, this means that the organization assigns people or defines jobs to deal with other organizations. Sometimes organizations are aware of the interdependence of other organizations but not of their own. This is defined as low organizational awareness (Litwak, 1970). It is quite possible that organizations can be in a state of interdependence and not recognize it. On the other hand, there are situations in which interdependence is stressed when none exists. Morris and Binstock (1966) report that al1 
too often agency personnel meet and attempt to coordinate activities when, in fact, there is not sufficient interdependence to warrant it. Litwak (1970) sums up his discussion of the concept of interdependence by formulating two hypotheses: (1) When organizations are aware of interdependence, formal modes of linkages are most effective. Organizational awareness leads to assignment of special personnel and establishes permanent forms of coordination, functions which are consistent with formal modes of linkages. (2) Where organizational awareness is asymmetrical (one organization aware and the other not) it is hypothesized that the most effective form of linkage is semiformal. This would be a compromise between the pressures of one organization for formality and the other for primary group linkages.

So far two components of interagency participation have been established: the structural components of complexity, centralization, and formalization, and the psychological component of awareness of organizational interdependence. Before discussing the process of interagency participation, it is essential to outline the nature and meaning of an interorganizational service network.

An interorganizational service network is formed when service organizations combine efforts to provide comprehensive service to a particular target group. Benson et a1. (1973) have stated that a service network is formed when a number of organizations engage in extensive interaction. However, this extensive interaction should be for the purpose of cooperating with each other and not for the purpose of engaging in competition with each other. 


\section{RELATIONSHIPS BETWEEN THE SELECTED \\ VARIABLES AND PARTICIPATION}

Using rate of program change as a measure of organizational change, Hage and Aiken (1967) hypothesize that there is a direct relationship between complexity and the rate of program change. They argue that the addition of new programs increases complexity in an organization by necessitating the addition of new or specialized positions, which in turn may create a need for more new programs. New ideas and techniques generate new programs, as do conflicts among different occupational specialties within an organization. The more professionalized the occupation, the greater the struggle to prove the need for expansion (Hage and Aiken, 1967).

Hage and Aiken (1967) argue that the degree to which workers pursue professional activities outside their organization (a measure of complexity) shares a positive correlation with the rate of program change within the organization. This is because involvement in extraorganizational professional activities heightens awareness of programmatic and technological developments within a profession (Thompson, 1965). Professionally active job occupants introduce new ideas to the organization, and the outcome is a high rate of program change. SimiTarly, Wilson (1966) demonstrates that diversity in an incentive system and task structure (a measure of complexity) has a positive relationship with suggestions for innovation and a negative relationship with the rate of innovations adopted. Victor Thompson (1965) argues that diversity in input of ideas (a measure of complexity) has a positive relationship with suggestions for innovation and adoption. A 
study reported by Carroll (1966) confirms that occupational specialties (a measure of complexity) have a positive relationship with innovation. Finally, Hage $(1965,1971)$ and Hage and Aiken $(1967,1970)$ have documented that there is a positive relationship between complexity and organizational change.

While complexity is positively related to organizational change, formalization is negatively related to organizational change. This is because formalization stresses rules and regulations rather than initiative for change. As Merton (1957) points out, emphasis on rules leads to overconformity and resistance to change. Highty codified jobs (a measure of formalization) that are closely supervised to insure conformity reduce the search for better ways of doing work. Hage and Aiken (1967) argue that such use of rules encourages ritualistic and unimaqinative behavior. Burns and Stalker (1961) and Thompson (1967) argue that rigid rule observation inhibits diffusion and communication of ideas, suppresses creativity, and consequentry is negatively associated with innovation. These authors aiso point out that rigid job codification and specification of roles retard innovation and creativity which may lead to organizational rigidity. On the basis of these theoretical arguments, Hage (1965) and Hage and Aiken (1967) conclude that there is a negative relationship between formalization and organizational change.

Centralization is alleged to be negatively related to organizational change because concentration of decision making in one or few persons insulates the organization from new ideas. Decentralization of decision making is positively related to organizational change because 
greater participation in agency-wide decisions increases the rate of program change in organizations ('Hage and Aiken, 1967). Decentralization allows for the interplay of a variety of occupational perspectives. As Thompson (1965) has argued, a centralized organization is one in which change can be, and frequently is, easily vetoed.

Hage and Aiken (1967) discuss two types of decisions: decisions about the control of resources, and decisions about the control of work. They argue that it is the centralization of decisions about organizational resources, not the centralization of work control, that is highly related to low rates of program change. Similarly, Burns and Stalker (1961), Thompson (1965), and Clark (1968) argue that concentration of decision making prevents imaginative solutions to problems and input from diverse sources, thereby hindering innovation. On the basis of these arguments, Hage and Aiken (1967) hypothesize that centralization and organizational change are negatively related.

\section{CONCEPTUALIZATION OF THE THESIS}

As Aram and Stratton (1973) point out, while there is increasing attention by scholars to the field of interorganizational relationships, much of the work has been focused on the theories explaining present arrangements. They recommend that studies by pursued which attempt to understand processes leading to the development of greater interagency cooperation.

Thus far, this writer has attempted to establish conceptually a relationship between interaqency participation in an interorqanizational service network and the orqanizational variables of complexity, 
formalization, and centralization, and the psycholoqical variable of awareness of interdependency. Based on theoretical considerations, this study assumes that interagency participation is the result of a decision making process. William H. Starbuck (1965) advances a theory that orqanizational growth and development is the outcome of a decision making process. The orqanization makes a decision to change or maintain a status quo. March and Simon (1958) also view the organization as a decision making structure. Thompson and McEven (1958) view the goal-setting process (which involves organizational change) as a decision making process. Similarly, Aiken and Hage (1967) view program change as a decision to adopt new programs. Therefore, organizational change is closely related to decision making because change, whether internally or externally induced, requires a decision by the organization. At some stage, explicitly or by default, a decision to change must be made by an organization. A "non-decision" is also a decision.

\section{DECISIONS INVOLVING CHANGE}

The decision to change is difficult to analyze and to study. Hage and Aiken (1967) point out that one of the difficulties in studying change is determination of an adequate definition of organizational change. Etzioni (1961) suggests that most organizational studies implicitly or explicitly involve the study of change of some variable or property.

Hage and Aiken (1967) overcome this problem by studying organizational decisions to adopt new programs or services. Thompson and 
McEven (1958) approach the problem by studying the goal-setting process of organizations. Joan Woodward (1965) examines organizational change by studying the decision to adopt new technology.

One of the $1 i^{t+t}$ le understood areas of scholarly research is interagency cooperation and coordination. With the enormous proliferation of organizations in the field of health, welfare, and other services, it has become increasingly important to coordinate services.

Coordinating agencies have found that target organizations exhibit resistance to many coordination attempts. Such resistance to coordination has been documented by 0'Brien and Wetle (1975) in their studies of coordination and conflict among service providers of an aging services network.

This negative attitude toward cooperation is the result of an organization's decision that its best interest is not to cooperate or to coordinate its services with other organizations. To identify reasons for organizational resistance to coordination, one needs to study a decision by an organization to participate or not to participate in a coordinated action.

In this study, organizational change will be examined by reviewing the decision by an organization to participate or not to participate in an interorganizational network. Benson et al. (1973) state that an interorganizational network is formed when a number of organizations engage in extensive interactions for purposes of cooperation. It is the contention of this study that a decision to participate in an interorganizational service network is a decision involving organizational change. This contention is based on a distinction between 
programmed routine decisions and non-programmed non-routine decisions.

Cyert et a1. (1956) have defined programmed and non-programmed deci-

sions as follows:

Decisions in organizations vary widely with respect to the extent to which the decision making process is programmed. At one extreme we have repetitive, well-defined problems (e.g., quality control or production lot size) involving tangible consideration, to which the economic models that call for finding the best among a set of pre-established alternatives can be applied rather 1iterally. In contrast to this, high programmed and usually rather detailed decisions are problems of a non-repetitive sort, often involving basic long-range questions about the whole strategy of the firm or some part of it, arising initially in a highly unstructured form and requiring a great deal of the kinds of search processes listed above. In this whole continuum, from great specificity and repetition to extreme vagueness and uniqueness, we will call decisions that 1 ie toward the former extreme programed and those lying toward the latter end non-programmed (Cyert et a. . 1956).

March and Simon (1958) call decisions involving innovation nonprogrammed decisions because they are non-routine and involve introducing changes in the organization. In this sense, it is appropriate to call a decision to participate in an interorganizational network a non-programmed decision because it is not something that an organization can handle routinely. As stated before, the decision to participate affects an organization's autonomy, domain, power and status because the organization must deal with "vagueness" and uncertainty.

\section{SUMMARY}

The Weberian model of bureaucracy is critically examined and evaluated. The structure of bureaucracy as it currentiy exists provides the starting point for examining the problem of interorganizational participation. Review of the literature indicates that struc- 
tural factors like complexity, formalization and centralization may determine the process of participation. In addition to these structural properties, a psychological factor of organizational awareness of interdependency has been identified. If an organization perceives interdependency as necessary to achieve its goals, it is more likely to participate in an interorganizational network.

Structural factors such as complexity, centralization, and formalization and a psychological iactor such as awareness of interdependency may hinder or enhance an organization's participation in an interorganizational network. Relationships between these organizational variables and a decision to participate require further research and study. 


\section{CHAPTER III}

\section{METHODOLOGY AND DESIGN}

People who write about methodology often forget that it is a matter of strategy, not of morals. There are neither good nor bad methods but only methods that are more or less effective under particular circumstances in reaching objectives on the way to distant goals (George C. Homans, 1950).

\section{POPULATION AND SAMPLE}

The study's population consists of organizations in the State of Oregon whose main function is to provide services to the elderly. The sample is purposive in nature, selected from urban, mixed urban/rural, and rural communities. The study was part of a larger project pursued by the Institute on Aging (Wetle and Montgomery, 1976). Much of the data described herein were derived from that project.

The sample consists of 175 organizations. Of this sample, 67 are located in urban communities, 56 are located in mixed urban/rural communities, and 52 are located in rural communities.

\section{COLLECTION AND PROCESSING OF QUANTITATIVE DATA}

A list of 175 organizations was prepared as a purposive sample. From each organization, two individuals were selected as respondents. First, a pilot study was conducted as a means of testing the items to be used in the in-depth interview and the mailed questionnaires. Eleven individuals representing eleven organizations were 
contacted and participated in the pilot study.

Second, in-depth interviews were attempted with 55 individuals representing 55 organizations. Of these individuals, 84 percent, or 46 individuals, representing 46 organizations completed the interview.

Finally, a mailed quesiionnaire was sent to 273 individuals, of which 45 percent, or 123 responded. This response resulted only after an extensive telephone follow-up process was instituted. Of these 123 respondents, 69 organizations were represented.

Whenever both the director and staff reported about the same organization, only the director's response has been used. This method has been adopted to treat each organization as a unit of analysis rather than treating each respondent as a unit of analysis. Information about the sample is provided in Table I.

All of the previous data were placed on computer cards with each organization identified by a code to insure confidentiality. The data were processed on the IBM computer at Portland State University using one-way frequency distribution, partial correlation and regression programs (Nie et a1., 1975). The findings were then in a form ready to be analyzed and reported.

\section{TABLE I}

SAMPLE OF THE STUDY

\begin{tabular}{|c|c|c|c|c|}
\hline & Mixed & Urban & Rural & Total \\
\hline $\begin{array}{l}\text { Pilot Study } \\
\text { In-Depth Interview } \\
\text { Mail Questionnaire }\end{array}$ & $\begin{array}{r}3 \\
15 \\
25\end{array}$ & $\begin{array}{r}5 \\
18 \\
24\end{array}$ & $\begin{array}{r}3 \\
13 \\
20\end{array}$ & $\begin{array}{l}11 \\
46 \\
69\end{array}$ \\
\hline Totals: & 43 & 47 & 36 & 129 \\
\hline
\end{tabular}


COLLECTION AND PROCESSING OF THE QUALITATIVE DATA

To collect data of a qualitative nature, six organizations were selected on the basis of involvement or lack of involvement with members of the aging service network. Two organizations were selected because of a high level of involvement, two for a medium level of involvement, and two for a low level of involvement.

The selection of the organizations to be used in the case studies was a two-phase process. First, the organizations were ranked in groups according to level of involvement as indicated by the earlier questionnaires and interviews. Organizations involved with five or more of the components of the dependent variable (decision to participate in an interorganizational network) were considered as "highly involved," those that indicated involvement with three or four of the components were considered "moderately involved," and those that indicated involvement with two or less of the components were considered to have a "low involvement." The second phase was to select two organizations from each group as representative of that group. Selection was made by the researcher and the director of the Institute on Aging who was involved in studying the aging service network. The director was involved because of his knowledge of the organizations and their degree of representativeness.

Since no instrument was found which could be used for conducting in-depth interviews for the purpose of collecting qualitative data on the decision making process, a framework for a focused interview was developed. The framework was used by the researcher as a guide and frame of reference for conducting unstructured in-depth interviews. 
The framework was divided into six parts, each part dealing with some aspect of the decision making process (see appendix B).

Notes were taken during interviews with each of the selected organizations. These notes, supplemented by the quantitative data, provided the information needed to evaluate each of the organizations.

STATEMENT OF HYPOTHESIS

Hypothesis 1: There is no significant relationship between the selected variables and a decision to participate in an interorganizational service network.

Hypothesis 2: There is no significant difference in the importance of the selected variables in relation to a decision to participate in an interorganizational service network.

\section{STATISTICAL DESIGN}

The statistical techniques used in this study are simple correlation, partial correlation, and multiple regression.

Simple correlation has been selected because it indicates the degree of internal consistency and relationship between components of the variables.

Partial correlation has been used to ascertain the relationship between the components of the dependent and independent variables, controlling for the effect of other independent variables.

Multiple regression has been used to determine the relationship between measures of the dependent variable and a set of selected independent variables. 
In analyzing the data, a correlation exceeding \pm .30 was considered significant and a correlation between \pm .15 to \pm .30 was considered to indicate a relationship worthy of further exploration. 


\section{CHAPTER IV}

ANALYSIS OF THE DATA

\section{INTRODUCTION}

The purpose of Chapter IV is to present and to discuss the findings of this study. This Chapter is organized into two major sections: the first discusses the statistical investigation of the data, while the second describes the Case Study component of the investigation.

\section{ANALYSIS OF THE RELATIONSHIP BETWEEN MEASURES \\ OF THE INDEPENDENT VARIABLES USING \\ ZERO-ORDER CORRELATION}

The study's independent variables were subjected to zero-order correlation analysis as a first step in the analytical process. The reasons were two-fold.

First, a number of authors have chronicled the results of their studies which indicate either a weak or no relationship between structural variables. As a check on the degree to which this organizational sample parallels qualities of organizations used in other studies, this analytical step indicates to some extent the generalization of findings to other organizational situations.

Second, the recent nature of the variable addressing awareness of interdependence precludes its inclusion in other studies addressing organizational characteristics. Such analysis here provides a check on the operational independence of this variable with respect to the other 
characteristics included in the study as independent variables.

Measures of the independent variables of complexity, formalization and centralization and results of the zero-order correlation are shown in Table II. The following strong relationships were found:

1. Complexity as indicated by organizational size negatively correlates to centralization indicated by staff participation in service decisions.

2. Complexity as indicated by levels of authority reflects correlation with formalization as indicated by the extent jobs are codified, and with centralization as indicated by amount of staff participation in program decisions.

3. Formalization as indicated by the extent jobs are codified is correlated with formalization as indicated by the extent going through proper channels is stressed and with centralization as indicated by the amount of staff participation in service decisions. A correlation is also evident with centralization as indicated by staff participation in program decisions.

4. Formalization as indicated by the extent going through proper channels is stressed evidences correlation with centralization as indicated by staff participation in program and service decisions.

5. Centralization as indicated by staff participation in service decisions is positively correlated with staff participation in program decisions but is negatively correlated with awareness of interdependency as indicated by the extent an organization perceives a need for community support.

6. Centralization as indicated by staff participation in program 
TABLE II

RELATIONSHIP BETWEEN MEASURES OF INDEPENDENT VARIABLES

\begin{tabular}{|c|c|c|c|c|c|c|c|c|}
\hline 1. Complexity as indicated by the organizational size & & & & & & & & \\
\hline $\begin{array}{l}\text { 2. Complexity as indicated by the levels of authority } \\
\text { within the organization }\end{array}$ & .18 & & & & & & & \\
\hline $\begin{array}{l}\text { 3. Formalization as indicated by the extent jobs are } \\
\text { codified }\end{array}$ & & .27 & & & & & & \\
\hline $\begin{array}{l}\text { 4. Formalization as indicated by the extent going throug } \\
\text { proper channels is stressed (rule observation) }\end{array}$ & & & .32 & & & & & \\
\hline $\begin{array}{l}\text { 5. Centralization as indicated by the extent staff } \\
\text { participated in service decisions }\end{array}$ & -.16 & .13 & .33 & .22 & & & & \\
\hline $\begin{array}{l}\text { 6. Centralization as indicated by the extent staff } \\
\text { participated in program decisions }\end{array}$ & & .25 & .26 & .23 & .68 & & & \\
\hline $\begin{array}{l}\text { 7. Awareness of interdependency as indicated by the } \\
\text { extent an organization perceives a need for } \\
\text { community support for goal attainment }\end{array}$ & & & & .12 & -.11 & -.11 & & \\
\hline $\begin{array}{l}\text { 8. Awareness of interdependency as indicated by percep- } \\
\text { tion of interrelatedness of programs with other } \\
\text { agencies }\end{array}$ & & .72 & & .73 & .13 & & & \\
\hline $\begin{array}{ll}\text { Note: } & \text { Blanks are less than } \pm .10 \\
& \pm .15 \text { to } \pm .30 \text {, worthy of further exploration } \\
& \pm .30 \text { and up, significant correlation }\end{array}$ & 1 & 2 & 3 & 4 & 5 & 6 & 7 & 8 \\
\hline
\end{tabular}


decisions also negatively correlates with an orqanization's perception of need for community support.

In studying the independent variables, one finds several correlations worthy of discussion. Centralization as indicated by amount of staff participation in program decisions is the variable with greatest frequency of positive correlation. It correlates with complexity as indicated by levels of authority in an organization, formalization as indicated by the extent jobs are codified, formalization as indicated by stress placed upon going through proper channels, and centralization as indicated by amount of staff participation in service decisions.

The inordinately high correlation between the two measures of centralization suggests that both indexes are indicators of the same concept, that of participatory decision making. Correlations involving other variables, although not as strong, would indicate that they might also be alternative indicators of the same concept. The weak correlations found when analyzing these variables support the major findings of 1 all et al. (1967) who found that relationships between size and other structural components were inconsistent. They also found that neitheir compleyity nor formalization can be implied from organizational size. They point out that size may be irrelevant in determining organizational structure, a finding not challenged in this study.

\section{ANALYSIS OF THE RELATIONSHIP BETWEEN MEASURES \\ OF THE DEPENDENT VARIABLE USING ZERO-ORDER CORRELATION}

The dependent variable was studied in terms of eight indicators of the organization's decision to participate in an interorganizational 
network. Since these measures were selected in order to provide operational indexes of the same phenomenon, it is to be expected that they would positively intercorrelate to varying degrees. Indeed, to the extent that correlations may be for the most part absent, the rationale behind their selection is jeopardized. Accordingly, this analys is provides a means of verifying that a minimum of unidimensionality exists between the various indexes of interorganizational activity. Three expectations should be satisfied. First, variables number two through eight should intercorrelate positively since each is a measure of interagency activity of relatively finite programmatic dimension. Second, the first variable should intercorrelate positively with other variables to the extent that interagency coordination is a general organizational value. Since the scope of the activity measured by this variable differs from the others, however, positive relations are not expected in all cases. Finally, intercorrelations between alternative measures of the same phenomenon should be higher than those found between different phenomena.

These expectations were for the most part realized, as is reflected in Table III.

When zero-order correlations were calculated for the eight indexes of the dependent variable, the following significant relationships were found:

1. The frequency of involvement of the organization with the coordinating agency positively correlated with the number of client referrals by the organization to other agencies, with the number of client referrals by the organization to the coordinating agency, with 


\section{TABLE III}

\section{RELATIONSHIP BETWEEN MEASURES OF DEPENDENT VARIABLE}

1. The frequency of involvement of the organization with the coordinating agency

2. The number of $c$ lient referrals by the organization to other agencies

3. The number of client referrals to the organization by other agencies

4. The number of client referrals by the organization to the coordinating agency

5. The number of client referrals to the organization by the coordinating agency

6. The number of times information was provided by the organization to other agencies

7. The number of times information was provided by the organization to the coordinating agency

8. The number of times information was provided to the organization by the coordinating agency

Note: $B$ lanks are less than \pm .10

\pm .15 to \pm .30 , worthy of further exploration

\pm .30 and up, significant correlation

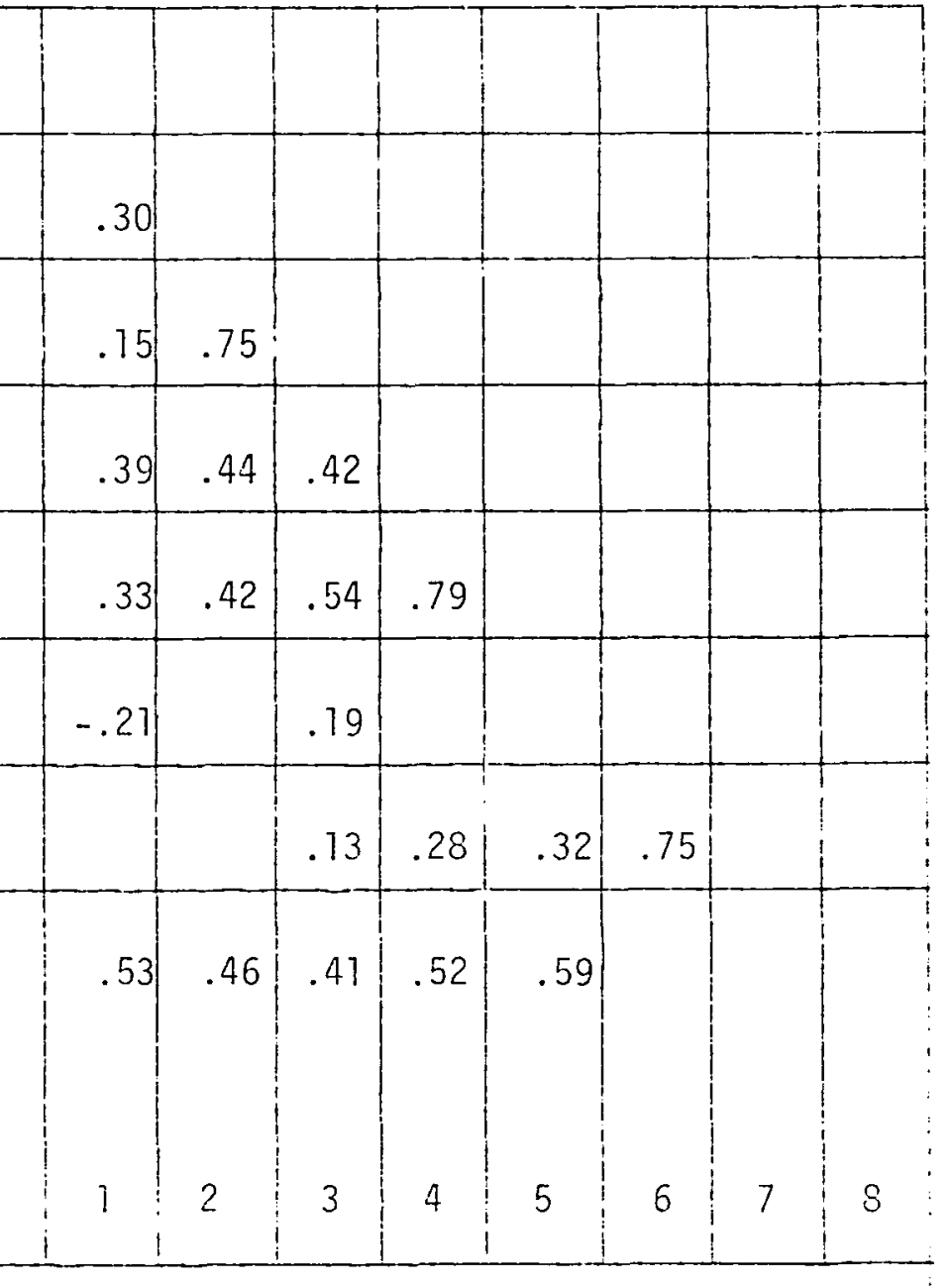


the number of client referrals to the organization by the coordinating agency, and with the number of times information was provided to the organization by the coordinating agency.

2. The number of client referrals by the organization to other agencies positively correlated with the number of client referrals to the organization by other agencies, with the number of client referrals by the organization to the coordinating agency, with the number of client referrals to the organization by the coordinating agency, and with the number of times information was provided to the organization by the coordinating agency.

3. The number of client referrals to the organization by other agencies positively correlated with the number of client referrais by the organization to the coordinating agency, with the number of client referrals to the organization by the coordinating agency, and with the number of times information was provided to the organization by the coordinating agency.

4. The number of client referrals by the organization to the coordinating agency positively correlated with the number of client referrals to the organization by the coordinating agency, and with the number of times information was provided to the organization by the coordinating agency.

5. The number of client referrals to the organization by the coordinating agency positively correlated with the number of times information was provided by the organization to the coordinating agency and with the number of times information was provided to the organization by the coordinating agency. 
6. The number of times information was provided by the organization to other agencies positively correlated with the number of times information was provided by the organization to the coordinating agency.

In addition to the above there were four correlations worthy of further exploration:

1. The frequency of involvement of the organization with the coordinating agency correlated with the number of client referrals to the organization by other agencies.

2. The number of client referrals to the organization by other agencies correlated with the number of times information was provided by the organization to other agencies.

3. The number of client referrals by the organization to the coordinating agency correlated with the number of times information was provided by the organization to the coordinating agency.

4. The only negative correlation emerged between the frequency of involvement of the organization with the coordinating agency and the number of times information was provided by the organization to other agencies.

The high correlations between the various measures of the dependent variable indicate that these are indexes of the decision to participate in an interorganizational network. 


\section{STATISTICAL ANALYSES OF THE RELATIONSHIPS BETWEEN THE INDEPENDENT VARIABLES AND MEASURES OF THE DEPENDENT VARIABLE}

Three statistical approaches were implemented in order to identify the relationships which exist between the study's independent and dependent variables. They were zero-order correlation analysis, multiple regression analysis, and multiple regression analysis incorporating controls on selected variables. They will be presented in the order described above and will be followed by a discussion of the findings.

Analys is of the Relationships Between The Independent Variables and Measures of the Dependent Variable Using Zero-Order Correlation

The purpose of this analysis is to help determine the nature and scope of the relationship between the independent variables and the various ineasures of the dependent variable. To do this, zero-order correlations were computed. The following significant relationships were found.

1. Complexity as indicated by organizational size was negatively correlated with the number of times information was provided by the organization to the coordinating agency.

2. Complexity as indicated by levels of authority in an organization correlated with the number of times information was provided by the coordinating agency.

3. Formalization as indicated by how jobs are codified correlated with the number of times information was provided to other agencies by the organization.

4. Formalization as indicated by stress placed upon going through 
RELATIONSHIPS BETHEEN INDEPENDENT VARIABLES AND MEASURES OF DEPENDENT VARIABLE: ZERO-ORDER CORRELATION ANALYSIS

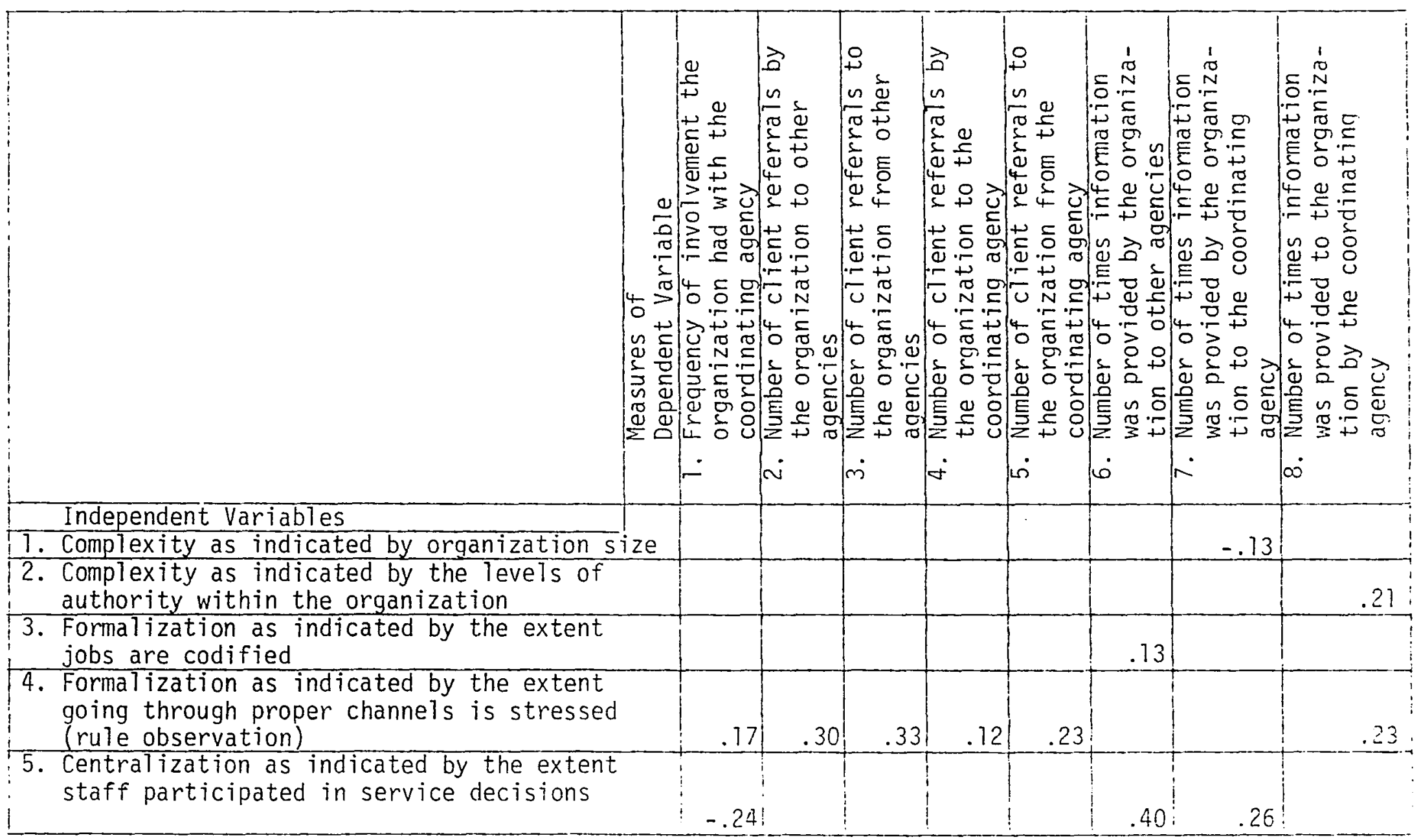




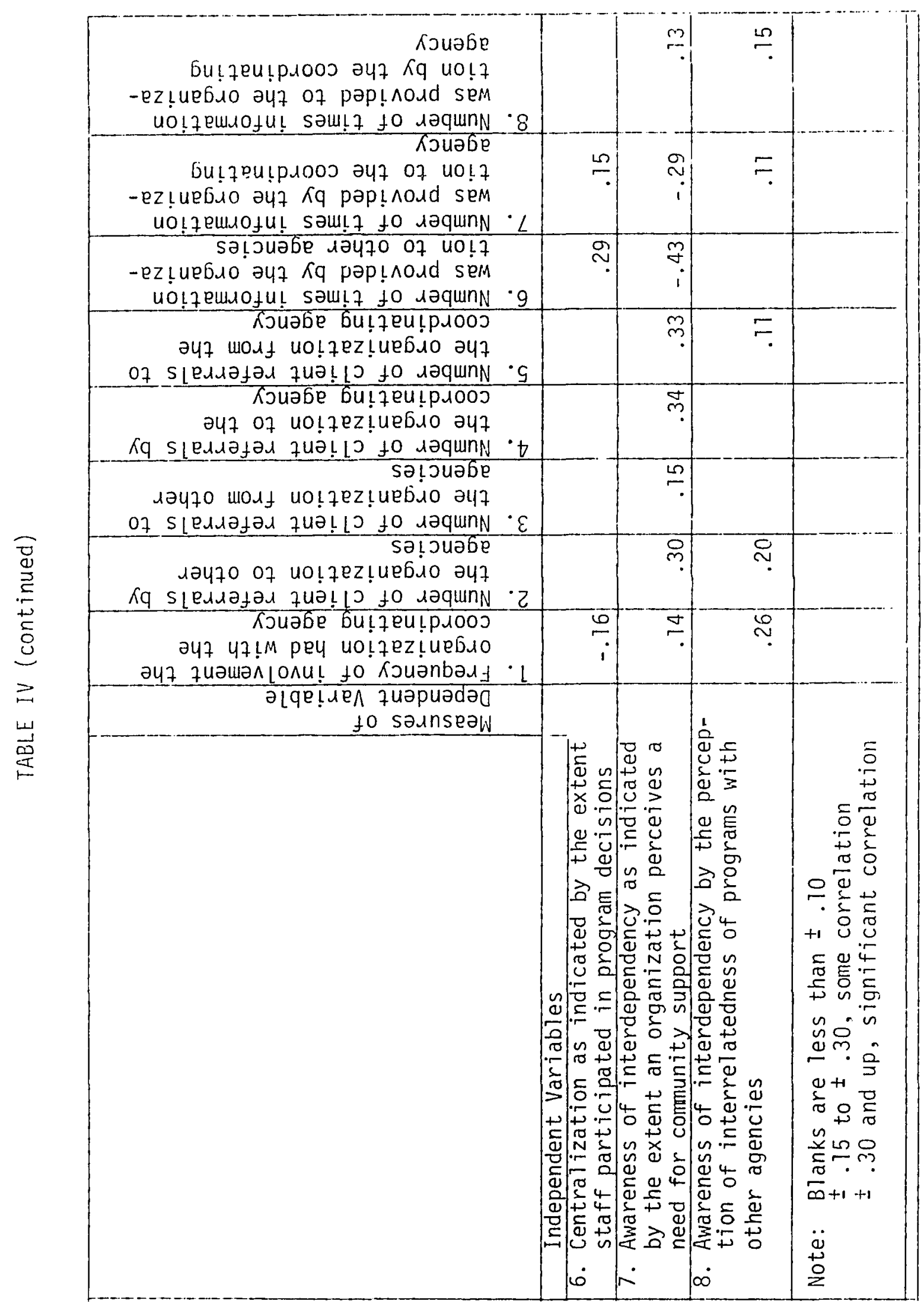


proper channels correlated with all indicators of the dependent variable except the number of times information was provided to other agencies by the organizations, and the number of times information was provided by the organization to the coordinating agency.

$5 \& 6$. Centralization as indicated by amount of staff participation in service decisions and centralization as indicated by amount of staff participation in program decisions negatively correlated with the frequency of involvement of an organization with the coordinating agency, but positively correlated with the number of times information was provided to other agencies by an organization, and the number of times information was provided by an organization to the coordinating agency

7. Interdependency as indicated by the perception of community support for goal attainment negativa? correlated with the number of times information was provided to other agencies by an organization, and the number of times information was provided by an organization to the coordinating agency, but positively correlated with all of the other indicators of the dependent variable.

8. Interdependency as indicated by the perception of an interrelationship of programs correlated with the frequency of involvement an organization had with the coordinating agency, with the number of clients referred to other agencies by an organization, with the number of $\mathrm{clients}$ referred to an organization by the coordinating agency, with the number of times information was provided by an organization to the coordinating agency, and with the number of times information was provided to an organization by the coordinating agency. 
Analysis of the Relationships Between the Independent Variables and Measures of the Dependent Variable Using Multiple Regression Analys is

The purpose of this analys is is to help determine the nature and scope of the relationship between the various indicators of the independent variables and components of the dependent variable. To do this, a multiple regression technique is used (see Table V).

When multiple regression coefficients were calculated for six measures of the independent variables and indexes of the dependent variable, the following relationships were found.

1. Complexity as indicated by levels of authority evidenced correlation with one component of the dependent variable, the number of times information was provided by the coordinating agency.

2. Formalization as indicated by stress placed upon going through proper channels correlated with four components of the dependent variable; number of $c$ lient referrals to other agencies, number of client referrals from other agencies, number of client referrals from the coordinating agency, and number of times information was provided by the coordinating agency.

3. Centralization as indicated by amount of staff participation in service decisions negatively correlated with one component of the dependent variable, frequency of involvement with the coordinating agency, but positively correlated with two measures of the dependent variable; number of times information was provided to other agencies, and number of times information was provided to the coordinating agency.

4. Centralization as indicated by amount of staff participation in program decisions positively correlated with one measure of the 


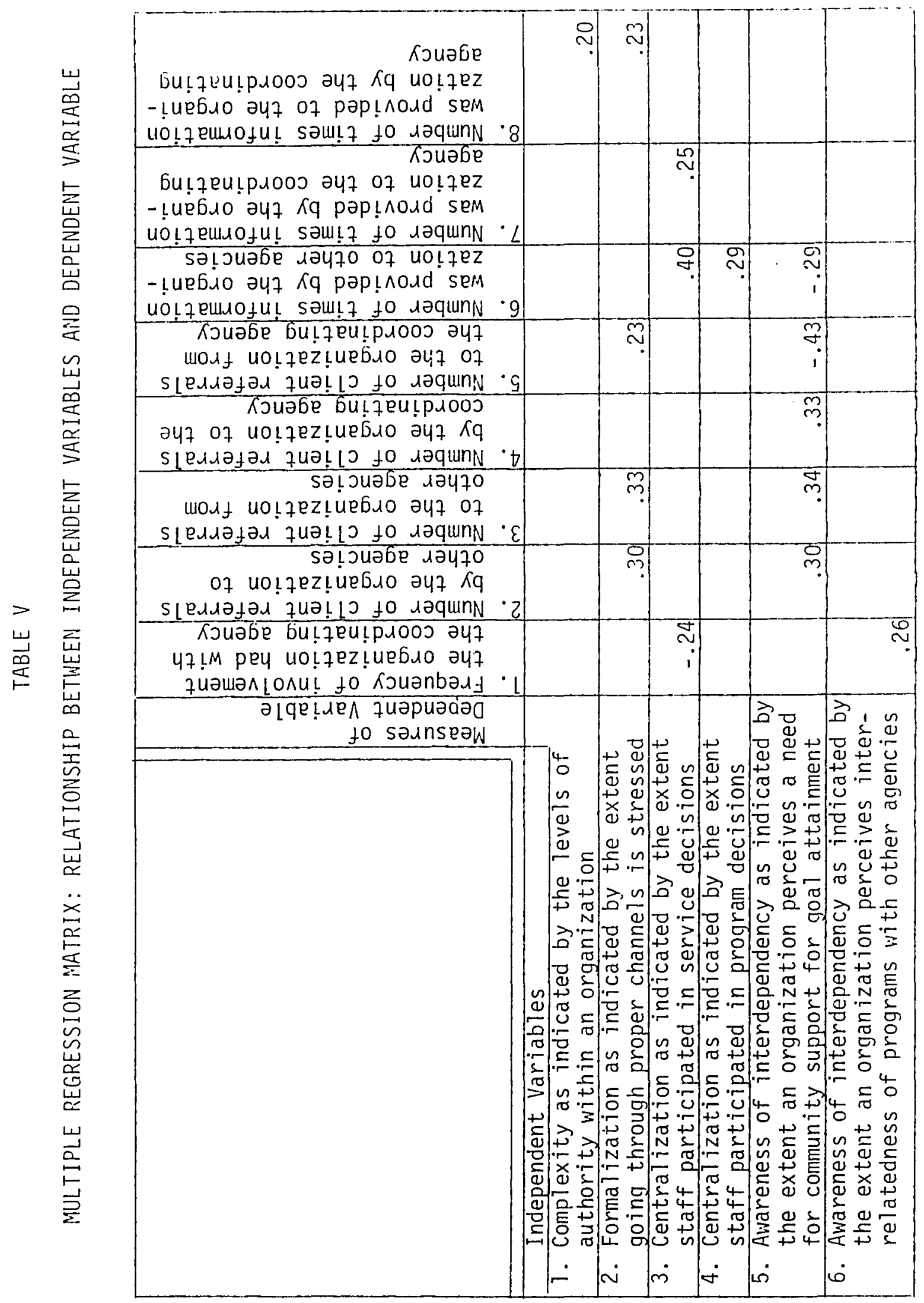


dependent variable, the number of times information was provided to other agencies.

5. Awareness of interdependency as indicated by the extent an organization perceives a need for community support for goal attainment positively correlated with three indexes of the dependent variable; number of client referrals to other agencies, number of client referrals from other agencies, and number of client referrals to the coordinating agency, but negatively correlated with two indexes of the dependent variables; number of client referrals from the coordinating agency and the number of times information was provided to other agencies.

6. Awareness of interdependency as indicated by the extent an organization perceives the interrelatedness of agency programs positively correlated with one measure of the dependent variable, frequency of involvement with the coordinating agency.

In studying the relationships between the independent variables and the eight measures of the dependent variable, it is worth noting the correlation between an awareness of interdependency as indicated by the extent the organization perceives a need for community support for goal attainment and several indexes of the dependent variable. The high correlation of this variable with the dependent variable indicates that this independent variable is a better predictor of a decision to participate than are the structural independent variables. 
Analysis of the Relationships Between the Independent Variables and Measures of the Dependent Variable while Controlling Selected Components of the Independent Variables

This phase of the analysis involves the computation of partial correlation coefficients between all independent variables and the eight operational proxies for the dependent variable, controlling in rotation for each of the independent variables. Any correlation less than \pm .10 is not discussed (see Table VI).

When formalization, centralization, and awareness of interdependency were controlled, the following partial correlation coefficients resulted.

1. Complexity as indicated by levels of authority to the number of times information was provided by the coordinating agency correlated .20 .

2. Complexity as indicated by organizational size:

a. the frequency of involvement with the coordinating agency correlated -.11

b. the number of times information was provided to the coordinating agency correlated -.13 .

With complexity, centralization and awareness of interdependency controlled, the following partial correlation coefficients resulted.

3. Formalization as indicated by the extent jobs are codified to the number of times information was provided to other agencies correlated .13 .

4. Formalization as indicated by the extent going through proper channels is stressed to:

a. the frequency of involvement with the coordinating agency 


\section{TABLE VI}

PARTIAL CORRELATION COEFFICIENTS BETWEEN MEASURES OF DEPENDENT VARIABLE AND EACH INDEPENDENT VARIABLE, WHILE

CONTROLLIN!G OTHER INDEPENDENT VARIABLES

\begin{tabular}{|c|c|c|c|c|}
\hline & Independent Variables & Measures of Dependent Variable & Controlling for: & $\begin{array}{l}\text { Partial } \\
\text { Correlation } \\
\text { Coefficients: }\end{array}$ \\
\hline 1. & $\begin{array}{l}\text { Complexity as indicated by } \\
\text { the levels of authority } \\
\text { within an organization }\end{array}$ & $\begin{array}{l}\text { Number of times information was } \\
\text { provided to the organization by } \\
\text { the coordinating agency }\end{array}$ & $\begin{array}{l}\text { Formal ization, central- } \\
\text { ization and awareness } \\
\text { of interdependency }\end{array}$ & .20 \\
\hline $2 \mathrm{a}$. & $\begin{array}{l}\text { Complexity as indicated } \\
\text { by the organizational } \\
\text { size }\end{array}$ & $\begin{array}{l}\text { Frequency of involvement the } \\
\text { organization had with the } \\
\text { coordinating agency }\end{array}$ & $\begin{array}{l}\text { Formalization, central- } \\
\text { ization and awareness } \\
\text { of interdependency }\end{array}$ & -.11 \\
\hline $2 b$. & $\begin{array}{l}\text { Complexity as indicated } \\
\text { by the organizational } \\
\text { size }\end{array}$ & $\begin{array}{l}\text { Number of times information was } \\
\text { provided by the organization to } \\
\text { the coordinating agency }\end{array}$ & $\begin{array}{l}\text { Formalization, central- } \\
\text { ization and awareness } \\
\text { of interdependency }\end{array}$ & -.13 \\
\hline 3. & $\begin{array}{l}\text { Formalization as indicated } \\
\text { by the extent the jobs } \\
\text { are codified }\end{array}$ & $\begin{array}{l}\text { Number of times information was } \\
\text { provided by the organization } \\
\text { to other agencies }\end{array}$ & $\begin{array}{l}\text { Complexity, centraliza- } \\
\text { tion and awareness of } \\
\text { interdependency }\end{array}$ & .73 \\
\hline $4 a$. & $\begin{array}{l}\text { Formalization as indicated } \\
\text { by the extent going } \\
\text { through proper channels } \\
\text { is stressed }\end{array}$ & $\begin{array}{l}\text { Frequency of involvement the } \\
\text { organization had with the } \\
\text { coordinating agency }\end{array}$ & $\begin{array}{l}\text { Complexity, centraliza- } \\
\text { tion and awareness of } \\
\text { interdependency }\end{array}$ & .17 \\
\hline $4 b$. & $\begin{array}{l}\text { Formalization as indicated } \\
\text { by the extent going } \\
\text { through proper channels } \\
\text { is stressed }\end{array}$ & $\begin{array}{l}\text { Number of client referrals } \\
\text { from the organization to } \\
\text { other agencies }\end{array}$ & $\begin{array}{l}\text { Complexity, centraliza- } \\
\text { tion and awareness of } \\
\text { interdependency }\end{array}$ & .30 \\
\hline
\end{tabular}


TABLE YI (continued)

\begin{tabular}{|c|c|c|c|c|}
\hline & Independent Variables & Measures of Dependent Variable & Controlling for: & $\begin{array}{l}\text { Partial } \\
\text { Correlation } \\
\text { Coefficients }\end{array}$ \\
\hline $4 c$ & $\begin{array}{l}\text { Formalization as indicated } \\
\text { by the extent going } \\
\text { through proper channels } \\
\text { is stressed }\end{array}$ & $\begin{array}{l}\text { Number of client referrals to } \\
\text { the organization from other } \\
\text { agencies }\end{array}$ & $\begin{array}{l}\text { Complexity, centraliza- } \\
\text { tion and awareness of } \\
\text { interdependency }\end{array}$ & .33 \\
\hline $4 d$. & $\begin{array}{l}\text { Formalization as indicated } \\
\text { by the extent going } \\
\text { through proper channels } \\
\text { is stressed }\end{array}$ & $\begin{array}{l}\text { Number of } c l i e n t \text { referrals } \\
\text { from the organization to the } \\
\text { coordinating agency }\end{array}$ & $\begin{array}{l}\text { Complexity, centraliza- } \\
\text { tion and awareness of } \\
\text { interdependency }\end{array}$ & .12 \\
\hline $4 \mathrm{e}$. & $\begin{array}{l}\text { Formalization as indicated } \\
\text { by the extent going } \\
\text { through proper channels } \\
\text { is stressed }\end{array}$ & $\begin{array}{l}\text { Number of client referrals to } \\
\text { the organization from the } \\
\text { coordinating agency }\end{array}$ & $\begin{array}{l}\text { Complexity, centraliza- } \\
\text { tion and awareness of } \\
\text { interdependency }\end{array}$ & .23 \\
\hline $4 f$. & $\begin{array}{l}\text { Formalization as indicated } \\
\text { by the extent going } \\
\text { through proper channels } \\
\text { is stressed }\end{array}$ & $\begin{array}{l}\text { Number of times information was } \\
\text { provided to the organization by } \\
\text { the coordinating agency }\end{array}$ & $\begin{array}{l}\text { Complexity, centraliza- } \\
\text { tion and awareness of } \\
\text { interdependency }\end{array}$ & .23 \\
\hline $5 a$. & $\begin{array}{l}\text { Centralization as indi- } \\
\text { cated by the extent staff } \\
\text { participated in service } \\
\text { decisions }\end{array}$ & $\begin{array}{l}\text { Frequency of involvement with } \\
\text { the organization with the } \\
\text { coordinating agency }\end{array}$ & $\begin{array}{l}\text { Complexity, formaliza- } \\
\text { tion and awareness of } \\
\text { interdependency }\end{array}$ & -.24 \\
\hline $5 \mathrm{~b}$. & $\begin{array}{l}\text { Centralization as indi- } \\
\text { cated by the extent staff } \\
\text { participated in service } \\
\text { decisions }\end{array}$ & $\begin{array}{l}\text { Number of times information was } \\
\text { provided by the organization to } \\
\text { other agencies }\end{array}$ & $\begin{array}{l}\text { Complexity, formaliza- } \\
\text { tion and awareness of } \\
\text { interdependency }\end{array}$ & .40 \\
\hline
\end{tabular}


TABLE VI (continued)

\begin{tabular}{|c|c|c|c|c|}
\hline & Independent Variables & Measures of Dependent Variable & Controlling for: & $\begin{array}{l}\text { Partial } \\
\text { Correlation } \\
\text { Coefficients }\end{array}$ \\
\hline $5 c$. & $\begin{array}{l}\text { Centralization as indi- } \\
\text { cated by the extent staff } \\
\text { participated in service } \\
\text { decisions }\end{array}$ & $\begin{array}{l}\text { Number of times information was } \\
\text { provided by the organization to } \\
\text { the coordinating agency }\end{array}$ & $\begin{array}{l}\text { Complexity, formaliza- } \\
\text { tion and awareness of } \\
\text { interdependency }\end{array}$ & .25 \\
\hline $6 a$. & $\begin{array}{l}\text { Centralization as indi- } \\
\text { cated by the extent staff } \\
\text { participated in program } \\
\text { decisions }\end{array}$ & $\begin{array}{l}\text { Frequency of involvement the } \\
\text { organization had with the } \\
\text { coordinating agency }\end{array}$ & $\begin{array}{l}\text { Complexity, formaliza- } \\
\text { tion and awareness of } \\
\text { interdependency }\end{array}$ & -.16 \\
\hline $6 b$. & $\begin{array}{l}\text { Centralization as indi- } \\
\text { cated by the extent staff } \\
\text { participated in program } \\
\text { decisions }\end{array}$ & $\begin{array}{l}\text { Number of times information was } \\
\text { provided by the organization } \\
\text { to other agencies }\end{array}$ & $\begin{array}{l}\text { Complexity, formaliza- } \\
\text { tion and awareness of } \\
\text { interdependency }\end{array}$ & .29 \\
\hline $7 a$. & $\begin{array}{l}\text { Awareness of interdepen- } \\
\text { dency as indicated by the } \\
\text { extent the organization } \\
\text { perceives a need for } \\
\text { community support for } \\
\text { goal attainment }\end{array}$ & $\begin{array}{l}\text { Frequency of involvement the } \\
\text { organization had with the } \\
\text { coordinating agency }\end{array}$ & $\begin{array}{l}\text { Complexity, centraliza- } \\
\text { tion and formalization }\end{array}$ & .14 \\
\hline $7 b$. & $\begin{array}{l}\text { Awareness of interdepen- } \\
\text { dency as indicated by the } \\
\text { extent the organization } \\
\text { perceives a need for } \\
\text { community support for } \\
\text { goal attainment }\end{array}$ & $\begin{array}{l}\text { Number of client referrals by } \\
\text { the organization to other } \\
\text { agencies }\end{array}$ & $\begin{array}{l}\text { Complexity, centraliza- } \\
\text { tion and formalization }\end{array}$ & .12 \\
\hline
\end{tabular}


TABLE VI (continued)

\begin{tabular}{|c|c|c|c|c|}
\hline & Independent Variables & Measures of Dependent Variable & Controlling for: & $\begin{array}{l}\text { Partial } \\
\text { Correlation } \\
\text { Coefficients }\end{array}$ \\
\hline $7 c$. & $\begin{array}{l}\text { Awareness of interdepen- } \\
\text { dency as indicated by the } \\
\text { extent the organization } \\
\text { perceives a need for } \\
\text { community support for } \\
\text { goal attainment }\end{array}$ & $\begin{array}{l}\text { Number of client referrals by } \\
\text { the organization to the } \\
\text { coordinating agency }\end{array}$ & $\begin{array}{l}\text { Complexity, centraliza- } \\
\text { tion and formalization }\end{array}$ & .14 \\
\hline $7 d$. & $\begin{array}{l}\text { Awareness of interdepen- } \\
\text { cy as indicated by the } \\
\text { extent ihe organization } \\
\text { perceives a need for } \\
\text { community support for } \\
\text { goal attainment }\end{array}$ & $\begin{array}{l}\text { Number of times information was } \\
\text { provided by the organization } \\
\text { to other agencies }\end{array}$ & $\begin{array}{l}\text { Complexity, centraliza- } \\
\text { tion and formalization }\end{array}$ & -.43 \\
\hline $7 e$. & $\begin{array}{l}\text { Awareness of interdepen- } \\
\text { dency as indicated by the } \\
\text { extent the organization } \\
\text { perceives a need for } \\
\text { community support for } \\
\text { goal attainment }\end{array}$ & $\begin{array}{l}\text { Number of times information was } \\
\text { provided to the organization by } \\
\text { the coordinating agency }\end{array}$ & $\begin{array}{l}\text { Complexity, centraliza- } \\
\text { tion and formalization }\end{array}$ & .13 \\
\hline $7 f$. & $\begin{array}{l}\text { Awareness of interdepen- } \\
\text { dency as indicated by the } \\
\text { extent the organization } \\
\text { perceives a need for } \\
\text { community support for } \\
\text { goal attainment }\end{array}$ & $\begin{array}{l}\text { Number of times information was } \\
\text { provided by the organization to } \\
\text { the coordinating agency }\end{array}$ & $\begin{array}{l}\text { Complexity, centraliza- } \\
\text { tion and formalization }\end{array}$ & -.29 \\
\hline
\end{tabular}


TABLE VI (continued)

\begin{tabular}{|c|c|c|c|c|}
\hline & Independent Variables & Measures of Dependent Variable & Controlling for: & $\begin{array}{l}\text { Partial } \\
\text { Correlation } \\
\text { Coefficients }\end{array}$ \\
\hline $8 a$. & $\begin{array}{l}\text { Awareness of interdepen- } \\
\text { dency as indicated by the } \\
\text { extent the organization } \\
\text { perceives the inter- } \\
\text { relationship of programs } \\
\text { with other agencies }\end{array}$ & $\begin{array}{l}\text { Frequency of involvement the } \\
\text { organization had with the } \\
\text { coordinating agency }\end{array}$ & $\begin{array}{l}\text { Complexity, centraliza- } \\
\text { tion and formalization }\end{array}$ & .26 \\
\hline $8 \mathrm{~b}$. & $\begin{array}{l}\text { Awareness of interdepen- } \\
\text { dency as indicated by the } \\
\text { extent the organization } \\
\text { perceives the inter- } \\
\text { relatedness of programs } \\
\text { with other agencies }\end{array}$ & $\begin{array}{l}\text { Number of client referrals by } \\
\text { the organization to other } \\
\text { agencies }\end{array}$ & $\begin{array}{l}\text { Complexity, centraliza- } \\
\text { tion and formalization }\end{array}$ & .20 \\
\hline $8 c$. & $\begin{array}{l}\text { Awareness of interdepen- } \\
\text { dency as indicated by the } \\
\text { extent the organization } \\
\text { perceives the inter- } \\
\text { relationship of programs } \\
\text { with other agencies }\end{array}$ & $\begin{array}{l}\text { Number of times information } \\
\text { was provided to the organiza- } \\
\text { tion by the coordinating } \\
\text { agency }\end{array}$ & $\begin{array}{l}\text { Complexity, centraliza- } \\
\text { tion and formalization }\end{array}$ & .15 \\
\hline
\end{tabular}


correlated .17 ;

b. the number of client referrals to other agencies correlated . 30 ;

c. the number of client referrals from other agencies correlated . 33 ;

d. the number of $c$ ient referrals to the coordinating agency correlated . 12 ;

e. the number of client referrals from the coordinating agency correlated .23;

$f$. the number of times information was provided by the coordinating agency correlated .23 .

When complexity, formalization, and awareness of interdependency were controlled, the following partial correlation coefficients resulted.

5. Centralization as indicated by staff participation in service decisions with:

a. the frequency of involvement with the coordinating agency correlated -.24 ;

b. the number of times information was provided to other agencies correlated .40 ;

c. the number of times information was provided to the coordinating agency correlated .25 .

6. Centralization as indicated by staff participation in program decisions to:

a. frequency of involvement with the coordinating agency correlated -.16; 
b. the number of times information was provided to other agencies correlated .29 .

With complexity, centralization, and formalization controlled, the following partial correlation coefficients resulted.

7. Awareness of interdependency as indicated by the extent an organization perceives a need for community support for goal attainment correlated with:

a. the frequency of involvement with the coordinating agency at .14

b. the number of client referials to other agencies at .12;

c. the number of client referrals to the coordinating agency at .14

d. the number of tines information was provided to other agencies at -.43

e. the number of times information was provided by the coordinating agency at .13

f. the number of times information was provided to the coordinating agency at -.29 .

8. Awareness of interdependency as indicated by the extent an organization perceives the interrelatedness of programs correlated with:

a. the frequency of involvement with the coordinating agency at .26

b. the number of client referrals to other agencies at .20

c. the number of times information was provided by the coordinating agency at .15 . 
Analysis of the Variance in Measures of the Dependent Variable Explained by the Independent Variables

To measure the variance accounted for by all the independent variables, a multiple regression analysis was implemented. The variance of each measure of the dependent variable explained by all of the independent variables used simultaneously was ascertained from the multiple correlation coefficient, which was squared to reflect the percent of variance explained.

It was found that variance accounted for by the independent variables was as follows (see Table VII):

1. frequency of involvement the organization had with the coordinating agency, 22 percent

2. number of client referrals by the organization to other agencies, 13 percent

3. number of client referrals to the organization from other agencies, 12 percent

4. number of client referrals by the organization to the coordinating agency, 7 percent

5. number of client referrals to the organizations from the coordinating agency, 8 percent

6. number of times information was provided by the organization to other agencies, 31 percent

7. number of times information was provided by the organization to the coordinating agency, 16 percent

8. number of times information was provided to the orqanization by the coordinating agency, 14 percent. 
TABLE VII

VARIANCE IN DEPENDENT VARIABLE EXPLAINED BY

A SET OF INDEPENDENT VARIABLES

\begin{tabular}{|c|c|c|}
\hline Measures of Dependent Variable & $\begin{array}{l}\text { A Set } \\
\text { Variab } \\
\text { Formal } \\
\text { zation } \\
\text { of Inte }\end{array}$ & $\begin{array}{l}\text { ident } \\
\text { lexity, } \\
\text { Centrali- } \\
\text { eness } \\
\text { icy }\end{array}$ \\
\hline \multirow[b]{2}{*}{$\begin{array}{l}\text { Frequency of involvement the } \\
\text { organization had with the } \\
\text { coordinating agency }\end{array}$} & $R$ & $R^{2}$ \\
\hline & .47 & .22 \\
\hline $\begin{array}{l}\text { 2. Number of client referrals by } \\
\text { the organization to other } \\
\text { agencies }\end{array}$ & .36 & .13 \\
\hline $\begin{array}{l}\text { 3. Number of client referrals to } \\
\text { the organization from other } \\
\text { agencies }\end{array}$ & .34 & .12 \\
\hline $\begin{array}{l}\text { 4. Number of client referrals by } \\
\text { the organization to the } \\
\text { coordinating agency }\end{array}$ & .24 & .07 \\
\hline $\begin{array}{l}\text { 5. Number of client referrals to } \\
\text { the organization from the } \\
\text { coordinating agency }\end{array}$ & .29 & .08 \\
\hline $\begin{array}{l}\text { 6. Number of times information was } \\
\text { provided by the organization to } \\
\text { other agencies }\end{array}$ & .56 & .31 \\
\hline $\begin{array}{l}\text { 7. Number of times information was } \\
\text { provided by the organization to } \\
\text { the coordinating agency }\end{array}$ & .40 & .16 \\
\hline $\begin{array}{l}\text { 8. Number of times information was } \\
\text { provided to the organization by } \\
\text { the coordinating agency }\end{array}$ & .37 & .14 \\
\hline
\end{tabular}




\section{DISCUSSION OF THE FINDINGS}

Analysis of selected organizational variables was undertaken to investigate their association with eight operational measures of the dependent variable, an organization's decision to participate in an interorganizational network.

The first independent variable analyzed was organizational complexity, as indicated by size and levels of authority. It was found that the size of the organization was not significantly related to any measure of the dependent variable. The number of levels of authority was found to be correlated with only one index of the dependent variable, information provided by the coordinating agency to the organization (see Table IV).

The above finding indicates that organizational complexity does not significantly affect the decision to participate, which supports the first hypothesis of this study. Complexity may be relevant to the rate of program change as reported by Hage and Aiken (1967), but does not seem to be relevant to the decision to participate as operationalized here. Complexity, however, may have relevance to the decision to participate in conjunction with other variables.

The second independent variable analyzed was organizational formalization. Two measures, job codification and rule observation, were used to operationalize formalization. Job codification indicated the extent to which the organization maintained a detailed job description and specification. Rule observation indicated the extent to which the organization enforced formal rules governing its operation.

It was found that job codification was not significantly related 
to any operationalization of the dependent variable. Rule observation was found to be significantly related to two measures of the dependent variable; client referrals by the organization to other agencies, and client referrals to the organization from other agencies. Rule observation was further found to exhibit lesser correlation with two other measures of the dependent variable; client referrals to the organization from the coordinating agency, and number of times information was provided to the organization by the coordinating agency (see Table IV).

The above findings support the hypothesized relationship between formalization and the dependent variable, inasmuch as client referrals to and from other agencies are the only indexes significantly related to participation. Reasons for formalization in terms of rule observation being supportive of interagency client referral are not altogether clear. Client referral is generally a non-threatening activity which does not involve adjustment on the part of the participating organization, so that an organization can generally engage in client referral without inviting commitment on its part.

The third independent variable analyzed was that of organizational centralization. Two operational proxies, service decision and program decision, were used to measure centralization. Service decision measured the extent to which the staff participated in making decisions about the administration of programs. Program decision measured the extent to which the staff participated in making decisions about introducing new programs.

The service decision measure of centralization was significantly related to only one operationalization of the dependent variable, 
number of times information was provided by the organization to other agencies. It also exhibited lesser relation to another component of the dependent variable, number of times information was provided by the organization to the coordinating agency, and was neqatively correlated with the frequency of involvement the organization had with the coordinating agency. The measure of centralization in program decisions was not significantly related to any component of the dependent variable, although it exhibited some relation to two indexes: number of times information was provided by the organization to other agencies, and to the coordinating agency. Staff participation in program decisions was also negatively correlated with the frequency of involvement the organization had with the coordinating agency (see Table IV).

The above findings indicate that organizational centralization significantly affects the decision to participate only in respect to one measure of the dependent variable, the number of times information was provided by the organization to other agencies. There are reasons why centralized decision making is associated only with this element of the decision to participate: exchange of information does not require participative decision making. Rather, members of organizations can exchange information without making internal changes or inviting firm commitments, so that participation through information exchange appears to be an activity which does not threaten the autonomy or power of the organization and may in fact enhance the organization's status, image, or doma in.

The fourth independent variable analyzed was the organization's awareness of interdependency. This variable was measured through two 
proxies; the extent to which the organization perceived a need for community support for goal attainnent, and the extent to which the organization perceived the interrelatedness of agency programs.

It was found that an organization's perception of a need for community support was significantly related to three components of the decision to participate; number of client referrals by the organization to other agencies, number of client referrals by the organization to the coordinating agency, and number of client referrals to the organization from the coordinating agency. It displayed a relationship to three measures of the decision to participate; the frequency of involvement the organization had with the coordinating agency, the number of client referrals to the organization from other agencies, and the number of times information was provided to the organization by the coordinating agency. Finally, the organization's perception of need for community support was strongly negatively correlated to two indexes of the dependent variable; number of times information was provided by the organization to other agencies and to the coordinating agency. An organization's perception of the interrelatedness of agency programs was not significantly correlated to any measure of the dependent variable, but did display relatively low relationships with five indexes (see Table IV) of the decision to enter a network. Although awareness of interdependency appears to be a better indicator of an organization's decision to participate than do the structural variables of complexity, formalization, and centralization, correlations do not indicate that it is a highly predictive variable. Awareness of a need for community support may be a better indicator 
because the perception of conmunity support by an organization tends to encourage the organization to exchange clients with other agencies regardless of what the organization's structural characteristics might be. On the other hand, an organization's perception of the interrelatedness of programs tends to encourage involvement with the coordinating agency to facilitate coordination with other agency programs. Together, these two factors account for the association between an organization's perception of the interrelatedness of its programs and its involvement with the coordinating agency.

When the association of each independent variable to the dependent variable was individually considered, the correlations were found to be significant with respect to only one independent variable, awareness of interdependency. But when the independent variables were considered as a set they significantly explained variance in the dependent variable. Working simultaneously, the independent variables were found to be significantly related to the frequency of involvement the organization had with the coordinating agency, the number of client referrals by the organization to other agencies, the number of client referrals to the organization from other agencies, the number of times information was provided by the organization to other agencies, the number of times information was provided by the organization to the coordinating agency, and the number of times information was provided to the organization by the coordinating agency. Further, these dependent variables exhibited lesser association with the number of client referrals by the organization to the coordinating agency and the number of client referrals to the organization from the coordinating agency 
(see Table VII).

The decision to participate and its association with the independent variables can be further explained if the independent variables are distinguished on the basis of their structural and non-structural characteristics. As explained earlier, the variables of complexity, formalization, and centralization, are structural variables while awareness of interdependency is a psychological variable. At this stage of the study, it is difficult to conclude whether structural or psychological variables are more significant in explaining the decision to participate. However, the distinction between the two has practical policy implications. The psychological variable is a manipulable variable, while the structural variables are best considered exogenous, or "given." While a coordinating agency may be able to change an organization's psychological perception of interdependency, it does not have much influence on the structural characteristics of the organization.

\section{QUALITATIVE CASE ANALYSIS OF THE RELATIONSHIPS \\ BETWEEN THE INDEPENDENT VARIABLES AND \\ OF THE DEPENDENT VARIABLE}

\section{Analysis of the Case Studies}

The case study method was used to collect qualitative data from six selected organizations. Two of the organizations were selected for a high level of involvement, two for a moderate level of involvement, and two for a low level of involvement. Qualitative data are needed to help interpret the overall findings of the study. For each organizastudied, the structure of the organization and a few of its decisions 
are presented.

CASE ONE

Introduction. This organization was established by the city to deal with problems related to alcohol abuse. It is designed to provide intensive and coordinated problem identification, treatment, and rehabilitation programs for the alcoholics on the city's "skid road." The goal of the organization is to restore each client to his or her maximum level of functioning as a citizen. Its target area is coextensive with the current urban renewal program in the city. Its target population is about 1,700 people.

The organization funds and supports four kinds of programs: (1) residential treatment, (2) emergency service, (3) support services, and (4) impact on service work. Although the organization does not direct its program at the aged inebriate, most of its clients are persons over the age of 65 .

Structure of the Organization. The organization is complex in terms of size and levels of authority. In addition to a citizen's advisory board, there are nine full time employees, in three departments and at five levels of authority.

The organization is highly formalized with respect to job codification, but not as formalized in adhering to organizational rules.

The decision making structure of the organization is decentralized. Decisions are made with participation and contribution from staff members. There are many layers of decision making, with each layer making contributions toward the final decision. It was observed that the organization has a high awareness of 
interdependency, both in respect to perception of need for community support and perception of interrelationship of progranis. In summary, the organization has a high degree of complexity, moderate degree of formalization, high degree of decentralization and a high awareness of interdependency.

Structure of Decision Making Process. The decision making structure of the organization consists of eight key actors:

(1) director of the organization, (2) citizens' advisory board, (3) city manager, (4) executive director of the bureau of human resources, (5) city commissioner, (6) city council, (7) program director of the National Institute of Alcoholism (NIA), and (8) grant specialist of the NIA.

A policy or program requiring a decision is considered by the director and his staff who prepare a proposal to be submitted to the citizens' advisory board which includes the city manager. The city manager submits the proposal to the executive director of the bureau of human resources, who in turn submits the proposal to the city council for final decision. The city council has final authority to accept or reject the proposal. If the proposal involves a grant from a government agency, then the agency's program director and grant specialist are asked to comment on the proposal and make recommendations. These are the specified steps in the decision making process. In practice the process can move back and forth before a final decision is made.

To ascertain how the process functions in actual situations, interviews for this study explored two specific organizational 
decisions: (1) to start a new program, and (2) to establish a referral system.

Decision to Start a New Program. In 1975, a decision was made to establish a new program called the "residential short-term program". It was designed to provide a short-term residential facility for clients until they were able to find a permanent place to live. The program provided room and board to needy clients. The original idea to establish the facility came from the National Institute of Alcoholism. The director and his staff prepared a detailed proposal which was submitted to the citizens' advisory board. The board submitted the proposal with its comments to the city manager, who in turn submitted the proposal to the executive director in charge of human resources. The executive director submitted the proposal to the city commissioner who passed it on to the city council. The city council then gave final approval to the program. The proposal passed three times between the director and the city council before it was finally approved.

Decision to Establish a Client Referral System. The organization did not formally establish a client referral system. An informal network of client referral and information exchange existed among the members of the aging services network. When this organization was established, it automatically became a member of the informal service network and as such was included in the client referral system.

Forces for and Arainst the Organization. The director felt that the program concept was supported by the community and the city council. He could not identify forces within the organization which were against the program. The police department and the director of the 
regional alcohol board did not support the program as it was operated. The police department wanted the organization to emphasize other justice administration programs. The director of the regional alcohol board, on the other hand, wanted the organization to spend more funds on residential treatment facilities rather than emergency or maintenance service facilities.

Motivation. According to the director, the motivating force behind establishment of this organization was the city's mayor who wanted to increase the tax base for the city by revitalizing the downtown area. The mayor viewed this program as an urban renewal project because he believed that the program would revitalize the downtown area by dealing with human and personal problems related to alcohol abuse. Motivation for the short-term residential program was to increase the funding base of the organization.

Constraints. The principal constraint in making effective decisions was the six layers of decision making. The complexity of the bureaucratic structure made effective and prompt decision making difficult.

The director viewed his organization as interdependent with other organizations in the social service network because problems related to alcohol abuse were multifaceted, requiring a multi-service approach to deal with them.

CASE TWO

Introduction. The purpose of this organization is to provide supportive services for the elderly, blind, and disabled. It provides these services through client referral, case monitoring, recreational 
activities, educational programs, transportation, escort services, housing placement, and emergency in-home services.

The director of the organization was responsible for its creation. While working at a hospital, he observed that once the elderly were discharged from the hospital there were no agencies to help them deal with problems encountered after leaving the hospital. Lack of postclinical care resulted in deterioration of an elderly person's health. The director discussed this problem with members of a church organization, and with administrators of nursing homes and other social service agencies. With the help of various religious and social organizations, the director was able to establish an agency to serve the impaired elderly.

Structure of the Organization. The organization is complex in size and levels of authority. It employs twenty full-time employees in four departments at four levels of authority, and has 152 active volunteers. The organization has a low degree of formalized structure, a low degree of job codification and a low degree of rule observation.

The decision making structure of the organization is decentralized. Decisions are made with full participation from staff and volunteers. It has several levels in the decision making structure, but at each level staff and volunteers are encouraged to participate in the process.

Members of the organization perceive a need for community support to accomplish organizational goals. They also believe in the interrelatedness of social service programs, and central coordination of social programs is favored to establish common priorities and service approaches among the organizations of the aging service network. 
Structure of the Decision Making Process. The decision making structure of the organization consists of four key actors: (1) director and his staff, (2) program committee, (3) chairman of the board of directors, and (4) board of directors.

A proposal or problem requiring a decision can originate from within or outside the organization. The proposal is reviewed by the director with input from his staff. He refers the proposal to the chairman of the board of directors. The chairman submits the proposal to the program committee which returns it to the board for final approval.

Three specific decisions were explored to ascertain how the decision making process functions: (1) decision to apply for governmental funds, (2) decision to serve on the advisory council of a coordinating agency, and (3) decision to establish a client referral system.

Decision to Apply for Federal Funds. The director learned of the availability of federal funding when he attended a meeting to inform the public about funds available to any organization which provided services to older Americans. Under this criterion, the director and staff felt their organization was qualified and applied for federal funds. They did not consider other funding options.

Decision to Serve on the Advisory Council of a Coordinating Agency. The organization did not make a formal decision to become a member of the advisory council of the coordinating agency. Membership was granted by the city commissioner and could have been refused. The organization accepted membership to encourage community support for its 
goals and because membership would provide a forum to seek support from other organizations in the community.

Decision to Establish a Client Referral System. The organization did not make a decision to establish a client referral network. It inherited the network from a federal project which was being phased out. The organization could have dismantled the network but it did not. Thus the acceptance of the network was considered a decision in favor of the network.

Constraints. The director felt that the major constraint to effective decision making was bureaucratic establishments such as the Area Agency on Aging. The Area Agency had been granted legal and financial powers by the federal government to mold and to shape the decisions made by service organizations. The director contended that a considerable amount of time and energy of his organization was wasted in power struggles with the bureaucracies over decision making.

\section{CASE THREE}

Introduction. This organization was established in 1952 as a family counseling agency. It is a non-profit volunteer organization with several sources of funding and provides services to clients of al1 ages.

Structure of the Organization. The organization is complex in terms of size and levels of authority. It has ninety full-time employees with varied professional backgrounds and service experience. Program coordinators are professional people with experience in social service delivery systems. The organization has eight departments and seven levels of authority. It has a moderate degree of formalized 
structure and a high degree of job codification, but a low degree of rule observation. Everybody has specific tasks, but staff are allowed to have some flexibility as far as rules and procedures are concerned. The decision making structure of the organization is decentralized, allowing participation of the staff and community leaders. Organization leaders perceive community support as essential to achieve objectives and that community support should come in the form of funding and recommending new programs. Organizational programs are seen as interrelated with other programs in the community and supportive of the concept of comprehensive coordinated services.

Structure of the Decision Making Process. The organization is divided into four service units. Each has a program coordinator who makes routine service and administrative decisions. Program coordinators are under the supervision of an associate director who is responsible to the executive director who is accountable to the board of directors.

Al1 policy and program decisions are made by the executive director with input from the associate director, program coordinators, and other members of the staff. The executive director makes final decisions with the board of directors acting in an advisory capacity.

A policy, program, or problem requiring a decision is reviewed by the associate director and then presented to the staff. The staff has an opportunity to comment, to criticize, or to contribute to the decision. The associate director, with input from the staff, makes recommendations to the executive director. The executive director consults the board of directors before making a final decision. 
Three specific decisions were explored to ascertain how the decision making process functions: (1) the decision to add a new program, (2) the decision to become a member of the advisory council of a coordinating agency, and (3) the decision to participate in a client referral system.

Decision to Add a New Program. The organization had a staff member with experience and expertise in the field of protective service for the elderly but who was not employed as protective service staff. Organization members felt that a new program should be started in the field of protective service to utilize the expertise of this staff member. In 1974 the organization received an offer from the city council to take over the protective service program from the county with the city providing funding. The request was discussed in a staff meeting, and the executive director in consultation with staff members. The board of directors decided to adopt the program.

Decision to Become A Member of an Advisory Councit to a Coordinating Agency. The organization was asked by a council on aging to become a member of the council's advisory board. The associate director and staff recommended to the executive director that the organization accept the membership.

Decision to Participate in a Client Referral System. The organization did not make a formal decision to participate in a client referral system. The client referral system was a part of the contract with governmental agencies which included the coordinating agency. The organization accepted this term of the contract because it viewed the referral system as an important component of a coordinated service 
network.

Constraints. According to the associate director, the main constraint to decision making was the agency's inability to meet the demand for services. However, the associate director was not in favor of further expansion of social programs, even if funds were available from government agencies. She contended that the organization was already receiving 53 percent of its funds from government agencies, and she viewed that percentage as being too high to maintain independence of the organization. She reasoned that from a long-term point of view, independence was more important than expanding the services. She advocated slow growth based on well-balanced funding sources.

\section{CASE FOUR}

Introduction. This organization was created by city statute thirty-five years ago. Its main function is to provide housing for low-income people, but it also provides other social services such as counseling, homemaking, security, transportation, recreation, medical and dental, and tax assistance. The major proportion of its clients are elderly.

Structure of the Organization. The organization has a high degree of complexity in size and levels of authority. It has more than 200 full-time employees within its three divisions and six levels of authority.

The organization has a moderate degree of formalized structure. It has a high degree of job codification, but a low degree of rule observation. As many professional and paraprofessional workers are 
employed, jobs are clearly described and codified. There is considerable flexibility in the way services are administered.

Decision making is decentralized, utilizing staff meetings for obtaining staff input. The organization has an elaborate decision making structure which tends to encourage participation from the staff, clients, and the community.

Community support is perceived as essential in the provision of services. Service programs are viewed as interrelated, and a comprehensive coordinated service network for the elderly is advocated. The contention is that programs and services for the elderly should be centrally coordinated to facilitate the working out of common priorities, service approaches, and target group strategies.

Structure of the Decision Making Process. The decision making structure of the organization consists of four key actors: (1) a board of directors, (2) an executive director, (3) an executive assistant, and (4) the heads of departments.

Participation of the key actors depends upon the type and nature of decisions. In general, policy and program decisions are made by the board, while administrative decisions are made by the executive director with input from staff, department heads, and clients. A policy, program, or problem decision is first discussed in a staff meeting, after which the executive director studies the proposal, taking into account recommendations by staff and clients. He sends the proposal, with his recommendations, to the board of directors who have the final authority to accept or reject the proposal.

To ascertain how the process worked in actual situations, two 
specific decisions made by the organization were explored: (1) the decision to become an advisory council member of the coordinating agency, and (2) the decision to participate in a client referral system.

Decision to Become a Member of the Advisory Council to a Coordinating Agency. A staff member of the organization felt that the organization should become a member of the advisory council to the coordinating agency because such a membership would provide an opportunity to come into contact with other service organizations in the community. Such contact might improve the quality of the services to the elderly. The proposal was presented to the staff and the executive director who approved the request and decided that a letter be uritten to the commission on aging expressing the organization's wish to become a member of the advisory council. In response to this letter, the commission on aging named the organization as a member of the advisory council.

Decision to Participate in a Client Referral System. It was felt that the organization's clients should receive more social services from other organizations in the community. To obtain such services, a client referral and information exchange system was needed. The proposal was presented to the staff who decided to develop a system of client referral and information exchange with other organizations in the community.

Constraints. The director identified two kinds of constraints to effective decision making: (1) budgetary constraints, and (2) constraints imposed by law. 
CASE FIVE

Introduction. This organization was established to administer one of the federal poverty programs. It was first administered by the Department of Health, Education and Welfare, but was placed under a municipal agency in 1973. The purpose of the organization is to improve conditions of older people, financially and socially.

Structure of the Organization. The organization has a low degree of complexity in terms of size and levels of authority. It has only two full-time employees, the director and a clerical person. There are no departments or levels of authority. It is a simple organization with 1 imited manpower and financial base.

AlT decisions are made by the director. There is no participation in the decision making process by staff member or clients. Decision Inaking is centralized.

The organization has a high degree of formalization. Jobs are codified and formal rules are sirictly observed. Community support is seen as desirable hui: not a major requirement in accomplishing goals.

Structure of the Decision Making Process. The decision making process is simple in this organization. All decisions are made by the director, whether administrative or program decisions.

During the study interview, the director was asked about some nonroutine decisions made in the organization since the program was established. The director could not think of any non-routine decisions for establishing new programs or services. 
CASE SIX

Introduction. This organization was part of a county government and specialized in a program of home maintenance and home insulation. It was funded by a council on aging to serve the elderly and disabled with various types of home maintenance and home insulation services. Its goal is to help older people remain in their homes rather than in institutions.

Structure of the Organization. The organization has a low degree of complexity in terms of size and levels of authority. It has eleven ful1-time employees and no departments or levels of authority. The program coordinator is the chief administrator, and all other employees are members of the home maintenance crew. The program coordinator is accountable to the county supervisor.

The organization has a low degree of formalized structure. It has a high degree of job codification and a high degree of rule observation. Each member of the organization performs a specific task, and rules and procedures for administration of the program are rigidly enforced by the county supervisors. Rules are so rigidly enforced that sometimes the program coordinator is forced to break them to help a needy client.

The decision making structure of the organization is highly centralized. The coordinator is the sole decision maker and perceives that the organization needs strong community support to achieve its goa Ts.

Structure of the Decision Making Process. The organization has a simple decision making structure. All the decisions are made by the 
program coordinator. During the study interview, questions were asked about policy or program decisions made in the organization. The coordinator could not think of any decision which could be considered non-routine and innovative. Since the organization was established, no new programs or services have been introduced.

\section{Discussion of the Findings}

This study of all 126 responding organizations to determine the association between the selected independent variables and the decision to participate is most appropriately considered a macro-study while selection of the six organizations for closer examination is a micro-study. The later phase of the analysis was implemented as an independent validation of the former.

Six organizations were selected for case studies; two with a high level of involvement, two with a moderate level of involvement, and two with a low level of involvement. It was found that associations between the selected variables and the decision to participate were not consistent. Examination of the highly and moderately involved organizations indicated that complexity was related to the decision to participate. These organizations were complex in terms of size and levels of authority. They had a moderate degree of formalization and a complex decision making structure. Finally, these organizations perceived a need for community support to accomplish their goals. The organizations with a low level of involvement were simple in terms of size, levels of authority and decision making, but had a high degree of formalization. Findings on the awareness of interdependency variable were inconsistent. The organization in Case Five perceived 
that it did not need community support to accomplish its goals, while Case Six perceived that community support was essential to achieve its objectives.

Findings of the case studies seem to support the hypothesized association between the selected independent variables and the decision to participate. The findings are not consistent and seem inconclusive. Therefore, the researcher is reluctant to draw definite conclusions based on the findings of the case studies. This low level of reliability could be due to error variance in individual responses to the interview questions. Inaccurate responses could have been made either consciously or unconsciously and are factors to consider which might be contingent upon the respondent's state of mind, physical state, interpretation, external conditions, and fluctuations and idiosyncrasies of human memory. Another possibility is that responses were accurate and that an explanation of the relationships between the independent variables and the decision to participate are not discernbile from this study. This condition might be the result of too small a sample, the method of selection of the sample, or possibly that the organizational structures of the sample did not significantly differ. As indicated before, this was an exploratory study and its purpose was to explore various dimensions of interorganizational participation. The study has highlighted the problems and parameters of such participation, and it has set the stage for further examination of the problem. An extended study with an appropriate research design may be able to generate definitive findings on the issue of interorganizational participation. 
CHAPTER $V$

SUMMARY, CONCLUSIONS, IMPLICATIONS, AND RECOMMENDATIONS

\section{INTRODUCTION}

The purpose of this study was to examine the relationship between selected variables and an organization's decision to participate in an interorganizational service network, and to ascertain the relative contributions of these variables to the decision to participate. The variables explored in this study were the complexity of organizations, the formalized structure of organizations, centralization of the decision making structure of organizations, and awareness of the interdependency of organizations.

Organizational complexity was measured by the number of paid employees and the levels of authority within the organization. Formalization was measured by the extent to which jobs were codified and the extent to which going through proper channels was stressed. Centralization was measured by the amount of staff participation in service and program decisions. Awareness of interdependency was measured by the extent to which an organization perceived a need for community support as a means of achieving objectives, and the extent to which the organization perceived the interrelatedness of agency programs. The decision to participate in an interorganizational service network was measured through the use of six operationalizations; the organization's frequency of involvement with the coordinating agency, the 
number of client referrals from other agencies, the number of client referrals to the coordinating agency, the number of client referrals from the coordinating agency, the number of times information was provided to the coordinating agency, and the number of times information was provided by the coordinating agency. As was explained earlier, these indexes of participation were employed as measurable proxies for the study's less easily addressed dependent variable, the decision to participate. Findings and conclusions are described in terms of the affirmative decision leading to the participation which was actually measured.

A review of the 1 iterature indicates that the bureaucratic structure of an organization may enhance or hinder an organization's decision to participate. Burns and Stalker (1961) have stated that there are two types of bureaucratic structures, the mechanistic and the organic. Aiken and Hage (1971) have suggested that a mechanistic structure tends to hinder an organization's decision to participate, while an organic structure tends to enhance the decision to participate. They have further suggested that the mechanistic structure has structural characteristics of low complexity, high formalization, and high centralization while the organic structure has a high complexity, low formalization, and low centralization. Review of the literature further indicates that a psychological variable may be associated with an organization's decision to participate. Matthew Tuite (1972) called it an organization's recognition of interdependency; Litwak and Haylton (1962) called it self-awareness of interdependency; and Hage (1971) called it an awareness of interdependency. 
It is the intent of this study to provide information helpfur to urban planners, social agency directors, social program administrators and others concerned with the task of creating a comprehensive coordinated social service delivery system.

The population of this study consisted of organizations in the State of Oregon whose main function is to provide services to the elderly. The sample consisted of 175 organizations. Of this sample, 67 were located in urban communities, 56 were located in mixed urban/ rural communities, and 52 were located in rural communities.

The statistical techniques employed were simple correlation, partial correlation, and multiple regression. Simple correlation was used because it indicates the degree of internal consistency and relationship between components of the variables. Partial correlation was used to ascertain relationships between components of the dependent and independent variables, controlling for the effect of some components of the independent variables. Multiple regression was used to determine the relationship between an operationalization of the dependent variable and a set of selected measures of the independent variables. In this data analysis, a correlation exceeding \pm .30 was considered significant and a correlation between \pm .15 to \pm .30 was considered to indicate a relationship worthy of further exploration.

SUMMARY OF THE FINDINGS

The following is a summary of the findings of this study.

1. The independent variable of organizational complexity as indicated by size is not significantly related to any component of the 
dependent variable. Complexity, as indicated by levels of authority, is related to one component of the dependent variable, the number of times information was provided to the organization by the coordinating agency. This finding differs from results of case studies' data which indicate the complexity is related to the decision to participate.

2. Organizational formalization as indicated by job codification is not significantly related to any component of the dependent variable. Formalization as indicated by rule observation has been found to be significantly correlated to two components of the dependent variable; the number of client referrals to other agencies, and the number of client referrals from other agencies. This variable has some correlation with three components of the dependent variable; the number of client referrals from the coordinating agency, the number of times information was provided by the coordinating agency and the frequency of involvement with the coordinating agency. This finding differs from results of case studies' data which indicates that formalization is associated with the decision to participate.

3. Organizational centralization as indicated by staff participation in service decisions is significantly correlated to only one component of the dependent variable, information provided to other agencies. It displays weaker relationships with the number of times information was provided to the coordinating agency. Centralization as indicated by staff participation in program decisions was not significantly correlated to any component of the dependent variable, although it has some relation to the number of times information was provided to other agencies and to the coordinating agency. This 
finding differs from results of case studies' data which indicate that centralization is associated with the decision to participate.

4. An organization's awareness of interdependence, as indicated by its perception of community support, is significantly related to three components of the decision to participate; the number of client referrals to other agencies, the number of client referrals to the coordinating agency, and the number of client referrals from the coordinating agency. Awareness of interdependency, as indicated by an organization's perception of the interrelatedness of programs, is not significantly related to any measure of the dependent variable, although it reflects real correlations to three components; the frequency of involvement with the coordinating agency, number of $c l$ ient referrals to other agencies, and number of times information was provided by the coordinating agency. This finding differs from results of case studies' data, which is inconclusive. The organization in Case Five perceived that it did not need community support to accomplish its goals, while Case Six perceived that community support was essential to achieve its objectives.

\section{CONCLUSIONS}

The following conclusions are derived from the findings of this study.

1. An organization's awareness of interdependency is related to the decision to participate in an interorganizational service network. This variable is a better predictor of participation than are the structural variables of complexity, formalization and centralization. 
2. Complexity is not related to the decision to participate. Complexity of an organization is not a sufficient condition to affect a decision to participate. It does, however, have some relevance when combined with other variables in explaining the variance in the dependent variable.

3. Formalization as indicated by the extent to which an organization maintains detailed job descriptions and specifications is not related to the decision to participate. Job codification is probably irrelevant to the decision to participate. Formalization as indicated by rule observation is related to an organization's decision to make client referrals to other agencies and to obtain client referrais from other agencies.

4. Centralization is related to an organization's decision to exchange information with other organizations and with the coordinating agency.

\section{IMPLICATIONS}

\section{Implications for Research}

Research in the field of interorganizational relations is very limited. The study by Aiken and Hage (1968) is one of the most important studies in the field. The main finding of their study was that the organizational variables of complexity, formalization, and centralization are associated with the rate of program change. They have hypothesized that a complex organization with a low degree of formalization and centralization is more likely to have a higher rate of program change than an organization which is less complex and more formalized 
and centralized. They did not view the rate of program change as a decision making process.

The relationship of Aiken and Hage's structural variables to the decision to participate in an interorganizational network was tested in this study. The findings are not conclusive, although there is enough evidence to indicate some association between these variables and the decision to participate. This study has gone beyond the hypothesis suggested by Aiken and Hage (1968) by demonstrating that structural variables alone cannot be used to predict a decision to participate: an additional psychological variable is needed to explain this phenomenon. This study shows that the organization's perception of interdependency is an important variable in establishing interorganizational linkages. This finding does not nullify those of Aiken and Hage (1968); instead it adds an additional dimension in explaining the interorganizational field of organizational linkages.

\section{Implications for Practice}

This study has some practical implications for coordinating agencies. In local communities, the federal government has established a coordinating agency, the Area Agency on Aging, under the 01der Americans Act. This agency is entrusted with the task of planning and coordinating agencies providing service to the elderly. On the question of coordination, this study has demonstrated that to promote coordination and cooperation among agencies, participation by the agencies is needed in various activities of the service network. This study has shown that such participation can be in the form of client referrals, information exchange, and subcontracts with the coordinating agency. 
The most important implication of this study is that there are two aspects of interorganizational participation; the non-affectable aspect which cannot be changed or modified by a coordinating agency and the affectable aspect which can be changed or modified. The nonaffectable aspect is organizational structure which a coordinating agency cannot change. It cannot, for example, change a simple organization into a complex organization. Structural characteristics are "given" as far as a coordinating agency is concerned. The affectable aspect of interagency participation is the psychological variable of awareness of interdependency. A coordinating agency can change or modify the perception of an agency by initiating various programs, using information technology and by encouraging agency participation in planning sessions, advisory council meetings, and public hearings.

\section{RECOMMENDATIONS FOR FURTHER RESEARCH}

The necessity for further research on some aspects of this study is recognized. This study has explored ways of determining the critical dimensions of interagency participation in a service network. In studying the issues and concepts associated with interagency participation, a framework, if not a theory of interagency participation has emerged. In subsequent studies, this framework should be refined. The eight measures of the dependent variable developed here, some of which were found to be significantly correlated, could be used to develop an index of participation.

Measures of the independent variables also need some refinement. These measures were not significantly correlated. The problem may be 
measurement rather than the concepts themselves. For instance, complexity is a sound organizational variable, but it is operationally defined in terms of size and levels of authority. It may be possible to refine such a concept if it is defined in more precise terms. An operational definition in terms of division of labor, hierarchical differentiation, and spatial dispersion may refine the concept. Similarly, formalization can be refined by defining it in terms of organizational roles, authority relations, communications, norms and sanctions, and procedures.

The variable of centralization can be refined by distinguishing two kinds of decisions: organizational decisions and work decisions. The first concerns the organization as a unit, while the second concerns a respondent's degree of control over his immediate work environment. According to Aiken and Hage (1968), an index of actual participation can be constructed by asking questions about organizational decisions. A scale of the hierarchy of authority can be developed by asking questions about work decisions.

Further refinement is in order with respect to the key informants of this study. In this study, as part of the larger study, a director and a staff member from each organization were selected as key informants. The selection of such informants may be appropriate for collecting data on complexity, but for measuring formalization, centralization, and awareness of interdependency, a cross section of organizational members should be selected.

The measuring instrument of perception of interdependency requires some refinement. In this study, this variable is measured by 
two indicators; the perception of community support and the interrelatedness of programs. The method used was a questionnaire. The problem with the questionnaire method is that people say one thing and do quite the opposite. This problem becomes acute on questions involving values held by society. People do not like to indicate disapproval of socially approved values. For these reasons, social scientists recommend the use of non-reactive or unobstructive measures such as examining organizational documents, participant observation, and other behavioral indicators of perception.

This study has been conducted by using a sample of organizations from an aging services network. To broaden the scope of the study, it could be replicated by using organizations from other service networks, such as health, education or welfare.

Probably the most fruitful line of inquiry would be to refine, to clarify, and to elaborate on the relationship between the two components of interagency participation, the structural component and the psychological component. A relationship between the two components has not been hypothesized in this study, but the data have indicated that the psychological component has primacy over the structural components. However, the exact nature and scope of primacy of the psychological structure is not known. To some extent the case studies' data have indicated that although the psychological structure has primacy over the structural components, the psychological structure by itself cannot result in interaqency participation. An aqency's structural components cannot by themselves result in interagency participation without having the cognitive basis of awareness of interdependency. However, these 
relationships are at best conjectures and hypotheses. They require further research and exploration. 


\section{A SELECTED BIBL IOGRAPHY}

AAA-TA 1976. Closing the Gaps: Strategies for Technical Assistance: A Technical Report to the Department of Health, Education and Welfare, Institute on Aging, Portland State University.

Aiken, Michael and Jerald Hage 1971. "The Organic Organization and Innovation," Sociology, 5:1, January, 63-82.

Aiken, Michael and Jerald Hage 1968. "Organizational Inter-dependence and Intra-organizational Structure," American Sociological Review, 33, December, 912-929.

Aiken, Michael and Jerald Hage 1966. "Organizational Alienation: A Comparative Anaiysis," American Sociological Review, 31 August, 497-507.

Aldrich, Hal1 1971. "ûrganizational Boundaries and Interorganizational Conflict," Hurnan Relations, 24, August, 279-293.

Allen, Louis 1973. "M for Management Theory Y Updated," Personnel Journal, December, 1061-1065.

Anderson, T. R. and S. Workov 1961. "Organizational Size and Functional Complexity: A Study of Administration in a Hospital," American Sociological Review, 26 February, 23-28.

Aram, John D. and William E. Stratton 1973. "The Development of Interagency Cooperation," Social Services Review, 48:2, June, $141-167$.

Argyris, Chris 1974. Behind the Front Page, San Francisco, Josey-Bass Publishers.

Argyris, Chris 1974. Theory in Practice, San Francisco, Josey-Bass Publishers.

Argyris, Chris 1973. "Personality and Organization Theory Revisited," Administrative Science Quarter7y, 18:2, June, 141-167.

Argyris, Chris 1972. The Applicability of Organizational Sociology, New York, McGraw-Hi11.

Argyris, Chris 1971. Management and Organizational Development, New York, McGraw-Hil1. 
Argyris, Chris 1970. Intervention Theory and Methods, Reading, Mass., Addison-Wesley.

Argyris, Chris 1965. Organization and Innovation, Homewood, Illinois, R. D. Irwin.

Argyris, Chris 1964. Integrating the Individual to Organization, New York, Wiley.

Argyris, Chris 1962. Interpersonal Competence and Organizational Effectiveness, Homewood, I7Tinois, Dorsey Press.

Argyris, Chris 1962. Social Science Approaches to Business Behavior, London, Tavistock.

Argyris, Chris 1960. Understanding Organizational Behavior, Homewood, Illinois, Dorsey Press.

Argyris, Chris 1957. Personality and Organization, New York, Harper.

Argyris, Chris 1953. Executive Leadership, New York, Harper.

Argyris, Chris 1952. An Introduction to Field Theory and Interaction Theory, Yale, Yale University.

Azumi, Koya 1972. "Toward a Synthesis: A System Perspective," in Hage, Jerald (ed.) Organizational System, Lexington, Mass.

Bauer, Raymond and Kenneth Gergen 1962. The Study of Policy Formation, New York, The Free Press.

Becker, S. W. and Gerald Gordon 1966. "An Entrepreneurial Theory of Formal Organization," Administrative Science Quarterly, December, 315-325.

Beckhard, Richard 1969. Organizational Strategies and Models, Reading, Mass., Addison-Westey.

Bendix, Reinhard 1968. "Bureaucracy" in International Encyclopedia of Social Sciences, Vol. II, New York, McMillan, 207.

Bendix, Reinhard 1962. Max Weber, New York, Doubleday Co.

Bennis, Warren G. 1967. Organizational Development: Its Nature, Origins and Prospects, Reading, Mass., Addison-Westey.

Bennis, Warren G. 1966. Changing Organizations, New York, McGraw-Hil7.

Bennis, Warren et a7. 1965. Personal and Organizational Change Through Group Methods, New York, Wiley. 
Bennis, Warren et a1. 1961. The Planning of Change, New York, Holt, Rinehart and Winston.

Bennis, Warren G. 1959. "Leadership Theory and Administrative Behavior," Administrative Science Quarterly, 4, 259-301.

Benson, J. Kenneth et a1. 1973. Coordinating Human Services: A Sociological Study of an Interorganizational Network, $A$ research series No. 6, Missouri University, Columbia, Regional Rehabilitation Research Institute, June.

Benton, John B. 1973. Managing the Organizational Process, Lexington, Mass., Lexington Books.

Bierstedt, Robert 1957. The Social Order, New York, McGraw-Hil1.

Blau, Peter M. 1968. "The Hierarchy of Authority in Organizations," The American Journal of Sociology, 73, 453-467.

Blau, Peter M. 1962. Formal Organizations, San Francisco, Chandler.

Blau, Peter M. and William R. Scott 1962. Formal Organizations, San Francisco, Chandler.

B7au, Peter M. 1956. Bureaucracy in Modern Society, New York, Random House.

Blumberg, Arthur and William Wiener 1971. "One From Two: Facilitating an Organizational Merger, " Journal of Applied Behavioral Sciences, 72, January-February.

Boguslaw, Robert 1965. The New Utopians: A Study of System Decision and Social Change, Englewood Cliffs, N. J., Prentice-Hall.

Bolton, Charles 1961. "Mate Selection," Marriage and Family, 23: August.

Boyer, William W. 1964. Bureaucracy on Trial, Policy Making by Government Agencies, Indianapolis, Bobbs-Merritl.

Brinkerhoff, Merlin B. and Philips Kunz 1972. Complex Organizations and Their Environments, Dubuque, Iowa, WiTliam C. Brown.

Burns, Tom and G. M. Stalker 1961. The Management of Innovation, London, Tavistock Publications.

Caplow, Theodore 1957. "Organizational Size," Administrative Science Quarterly, 1, March, 484-505.

Carro17, Jean 1966. "A Note on Departmental Autonomy and Innovation in Medical Schools, The Journal of Business, 49:531. 
Chapl in, Stuart F. 1951. "The Growth of Bureaucracy: An Hypothes is," American Socioloqical Review, 16, December, 835-836.

Churchman, West 1961. Prediction and Optimal Decision, Englewood Cliffs, N. J., Prentice-HalT.

Clark, Terry N. 1968. Community Structure and Decision Making, San Francisco, Chandler.

Coch, L. and J. R. P. French, Jr. 1948. "Overcoming Resistance to Change," Human Relations, 1, 512-532.

Cochrane, James 1973. Multiple Criteria Decision Makina, Columbia, University of South Carolina.

Collins, Barry E. 1964. A Social Psychology of Group Processes, New York, Wiley.

Corwin, Roland G. 1972. "Strategies for Organizational Innovation: An Empirical Comparison," American Sociological Review, 37, 441.

Coser, Lewis 1971. Masters of Sociological Thought, New York, Harcourt, Brace, Jovanovitch.

Cox, Robert 1973. The Anatomy of Influence: Decision Making in International Organization, New Haven, Yale University Press.

Cyert, Richard and James March 1963. A Behavioral Theory of the Firm, Englewood Cliffs, N. J., Prentice-Hall.

Cyert, Richard et a1. 1958. "The Role of Expectations in Business Decision Making," Administrative Science Quarterly, 3, 307.

Cyert, Richard et a1. 1956. "Observation of a Business Decision," Journal of Business, 29:237-248.

Dalton, Gene W. 1970. Organizational Change, Homewood, I11inois, R. D. Irwin.

Davis, Morris 1969. Metropolitan Decision Process, Chicago, Rand McNally.

Douglas, Brown J. 1973. The Human Nature of Organization, New York, AMACOM.

Dror, Yehezkel 1968. Public Policy Making Reexamined, San Francisco, Chandier.

Duncan, Robert 1972. "Characteristics of Organizational Environment and Perceived Environmental Uncertainty," Administrative Science Quarterly, $17,313$. 
Eisenstadt, S. N. 1959. "Bureaucracy, Bureaucratization and Debureaucratization," Administrative Science Quarterly, 4, 302, No. 3, December.

Elbing, Alvar 1970. Behavioral Decisions in Oraanization, Glenview, Illinois, Scott Foresman.

E11 iott, Grace 1959. How to Help Groups Make Decisions, New York, Association Press.

Emery, F. E. and E. L. Trist 1965. "The Causal Texture of Organization Environments," Human Relations, 18, February, 21-32.

Etzioni, Amitai 1964. Modern Organizations, Englewood Cliffs, N. J., Prentice-Hall.

Etzioni, Amitai 1961. Complex Organizations: A Sociological Reader, New York, The Free Press.

Evan, William M. 1966. "The Organization Set: Toward a Theory of Organizational Relations," in Thompson, James D. (ed.), Approaches to Organizational Design, Pittsburgh, University of Pittsburgh Press, 173-188.

Evans, William and Guy Black 1967. "Innovation in Business Organizations," The Journal of Business, 40, 519.

Fairweather, William 1974. Introducing Change in Mental Health Organization, New York, Pergaman Press.

Faludi, Andreas 1973. A Reader in Planning Theory, New York, Pergaman Press.

Festinger, Leon 1964. Conflict, Decision and Dissonance, Stanford, California, Stanford University Press.

Fink, Beak and Taddeo 1971. "Organizational Crisis and Change," Journal of Applied Behavioral Science, Vo1. 7, 15.

Fox, Lawrence 1966. A Decision Making Model for College Administration, Ann Arbor, Michigan.

French, Wendell L. 1972. Organizational Development, Englewood Cliffs, N. J., Prentice-Hall.

Gamson, William A. 1961. "A Theory of Coalition Formation," American Sociological Review, 26.

Garth, Jones 1969. Planned Organizational Change, Praeger.

Ginsberg, Eli and Ewing W. Reilly 1958. Effecting Changes in Large Organizations, New York, Columbia University Press. 
Gluckman, M. 1971. "New Dimensions of Change, Conflict and Settlement," International Social Science Journal, 23, 4, 548.

Goodnough, Warren H. 1963. Cooperation in Chanqe, New York, Russe11 Saqe Foundation.

Gore, William J. 1964. Administrative Decision Making, New York, Wiley.

Greiner, Larry 1967. "Antecedents of P7 anned Organizational Change," Journal of Applied Behavioral Science, 3, 57-85.

Grosof, L. H. et a1. 1970. "Anchorage in Organization," Social Forces, 49, September, 81-90.

Grusky, 0scar 1961. "Corporate Size, Bureaucratization and Managerial Succession," American Journal of Sociology, 67, November, 261-269.

Guest, R. H. 1969. Organizational Change, Homewood, I17inois, Dorsey Press.

Haas, Eugene et al. 1963. "The Size of the Supportive Component in Organizations: A Multi-Organizational Analysis," Social Forces, 42, October, 9-17.

Hage, Jerald and Robert Dewar 1973. "Elite Values Versus Organizational Structure in Prediction of Innovation," Administrative Science Quarteriy, September, 18(3), 279-290.

Hage, Jerald and Azumi Koya 1972. Organizational System: A Reader in the Sociology of Organization, Heath.

Hage, Jerald 1971. "A Strategy for Creating Interdependent Delivery Systems to Meet Complex Needs," in Anat R. Negandhi (ed.), Interorganization Theory, Kent, Kent State University Press.

Haqe, Jerald and Michael Aiken 1970. Social Change in Complex Organization, New York, Random House.

Hage, Jerald and Michael Aiken 1967. "Program Change and Organizational Properties," American Journal of Sociology, 72, March, 503-519.

Hage, Jerald 1965. "An Axiomatic Theory of Organization," Administrative Science Quarterly, X, December, 289-330.

Hal1, Richard 1972. The Formal Organization, New York, Basic Books.

Ha17, Richard 1972. Organizational Structure and Process, Englewood Cliffs, N. J., Prentice-Hal]. 
Hall, Richard 1968. "Professionalization and Bureaucratization," American Socioloqical Review, 33, 92-104.

Ha11, Richard et a1. 1967. "Organizational Size, Complexity and Formalization," American Sociological Review, 32, 903-912.

Ha11, Richard 1963. "The Concept of Bureaucracy: An Empirical Assessment," American Journal of Sociology, 69, 33-40.

Hawley, Amos, Walter Boland, and Margaret Boland 1965. "Population Size and Administration in Institutions of Higher Education," American Sociological Review, 30, Apri1, 252-255.

Heskett, J. L. and Roland H. Ballou 1966. "Logistical Planning in Interorganizational System," in M. P. Hottenstein and R. W. William (eds.), Research Toward Development of Management Thought, San Francisco.

Homans, George C. 1950. The Human Group, New York, Harcourt, Brace and World.

Homans, George C. 1949. "The Strategy of Industrial Sociology," American Journal of Sociology, 54, 330-339.

Jedamus, Paul 1969. Business Decision Theory, New York, McGraw-Hill.

Johnsen, Erik 1968. Studies in Multi-Objectives Decision Models, Lund, Student Literature.

Kahn, Robert et a1. 1964. Organizational Stress, New York, Wiley.

Kaluzny, Arnold et a1. 1972. "Innovations of Health Services," Working Paper, University of North Carolina.

Kaplan, A. D. H. et a1. 1958. Pricing in Big Business: A Case Approach, Washington, Brookings.

Kaplan, Berton H. 1968. "A Non-Weberian Model of Bureaucracy,." Administrative Science Quarterly, 13, 471-483.

Kassouf, Sheen 1970. Normative Decision Making, Englewood Cliffs, N. J., Prentice-Hall.

Katz, D. and R. L. Kahn 1966. The Social Psychology of Organization, New York, John Wiley.

Kaufman, Arnold 1968. The Science of Decision Making, Weidenfeld and Nicolson.

Kaufman, Herbert 1971. The Limits of Organizational Change, University of Alabama Press. 
Kepner, Charles 1965. The Rational Manager: A Systematic Approach to Decision Making, New York, McGraw-Hill.

Kerlinger, Fred N. 1972. Foundations of Behavioral Research, New York, Holt, Rinehart and Winston.

Klietsch, Roland 1961. Decision Making in Dairy Farming, unpublished doctoral dissertation, University of Minnesota.

Kogan, Nathan 1964. Risk-Taking: A Study in Cognition and Personality, New York, Holt, Rinehart and Winston.

Lawrence, Paul L. 1958. The Changing of Organizational Behavior Patterns, Boston, Harvard University Press.

Lawrence, Paul and Jay Lorsch 1967. "Differentiation and Integration in Complex Organizations," Administrative Science Quarterly, 12, $1-47$.

Leavitt, Harold 1971. "The Yesterday, To-day and Tomorrow of Organization," European Business, Spring, 28-88.

Leavitt, Harold 1965. "Applied Organizational Change in Industry," in James Marsh, Handbook of Organization, Chicago, Rand McNally.

Lee, Wayne 1971. Decision Theory and Human Behavior, New York, Wiley.

Levine, Sol et al. 1963. "The Community Interorganizational Problems in Providing Medical Care and Social Services," American Journal of Public Health, 53, August, 1183-1795.

Levine, Sol and Paul E. White 1961. "Exchange as a Conceptual Framework for the Study of Interorganizational Relationships," Administrative Science Quarterly, March.

Lindblom, Charles E. 1959. "The Science of Muddling Through," Public Administration Review, Spring, 79-88.

Lippett, R. Watson et a7. 1958. The Dynamics of Planned Change, New York, Harcourt, Brace.

Litchfield, Edward 1956. "Notes on a General Theory of Administration," Administrative Science Quarterly, 1, June, 3-29.

Littre17, W. Boyd 1969. "Complex Organization: Models and Reality," Rock Mountain Social Change Journal, 6, 2, 155-162.

Litwak, Eugene 1970. "Toward the Theory and Practice of Coordination Between Formal Organizations," in Rosengren and Lefton (eds.) Organizations and Clients, Ohio, Merrili. 
Litwak, Eugene and Lydia Hylton 1962. "Interorganizational Analysis: A Hypothesis on Coordinating Agencies," Administrative Science Quarterly, 6, March, 395-420.

Lorsch, Jay and Paul Lawrence 1970. Studies in Organization Design, Homewood, I11 inois, Dorsey Press.

Lyden, Fremont et al. 1969. Policies Decisions and Organization, New York, Appleton-Century Crofts.

Mack, Ruth 1971. Planning on Uncertainty, New York, Wiley.

Mailick, Sidney 1962. Concepts and Issues in Administrative Behavior, Englewood Cliffs, N. J., Prentice-HaTl.

Maiolo, J. R. 1970. "Organization for Social Action," Sociology Quarterly, 11, Fa11, 463-473.

Maniha, John and Perrow 1965. "The Reluctant Organization and the Aggressive Environment," 10, September, 246-257.

March, James and Herbert Simon 1958. Organizations, New York, Wiley.

Márcus, Alexis 1967. Organizational Decision Making, Englewood Cliffs, N. J., Prentice- $\overline{\mathrm{Ha} T \mathrm{~T}}$.

Marschak, T. A. 1962. Strategy and Organization in a System Development Project, New York, Princeton.

Martindale, Don 1959. "Sociological Theory and the Ideal Type," Llewellyn Gross (ed.), Symposium on Sociological Theory, New York, Row, Peterson.

Martino, R. 1969. Decision Patterns, Wayne, Pennsylvania, Management Development Institute.

McMahone, J. 1973. "Toward a Contingency Theory of Organizational Control," Academy of Management Journal, 16, 4.

McNeil, Thompson 1971. "Regeneration of Social Organization," American Sociological Review, 36, 624-637.

McNulty, J. E. 1962. "Organizational Change in Growing Enterprises," Administrative Science Quarterly, 7, 1-21.

Merton, Robert 1957. Social Theory and Social Structure, New York, The Free Press.

Messinger, S. 1955. "Organizational Transformation," American Sociological Review, 20, 3-10. 
Miller, David 1967. The Structure of Human Decisions, Englewood Cliffs, N. J., Prentice-HalT.

Mi17s, Warner 1962. Sma11 City: Seven Cases in Decision Making, New York, Random House.

Morris, R. and H. R. Binstock 1966 . Feasible Planning for Social Change, Columbia University Press.

Morrissey, Joseph et al. 1975. "Interorganizational Relations: Directions for Further Research," a paper presented at the 70th annual meeting of the American Sociological Association, August.

Morse, Nancy and Everett Reimer 1955. "The Experimental Change of Major Organizational Variable," Journal of Abnormal and Social Psychology, LII.

Mytinqer, Robert 1968. "Innovation in Local Health Services," Public Health Service Division of Medical Care, H.E.W., Arlington, Va.

Nie, et al. 1975. Statistical Package for the Social Sciences, New York, McGraw-Hi17.

Norman, Richard 1971. "Organizational Innovativeness," Administrative Science Quarterly, 16, 203-215.

O'Brien, John and Terrie Wetle 1976. "The Problem of Exchange Theory for Interorganizational Analysis: A Critical Review," a paper presented at the annual meeting of the American Sociological Association, New York, 1976.

0'Brien, John and Terrie Wet7e 1975. "The Study of Conflict and Coordination of Human Service Organization," a technical report to the Department of Health, Education and Welfare, Institute on Aging, Portland State University.

Parsons, T. 1970. "How Clients are Integrated into Service Organizations," in Rosengren and Lefton (eds.) Organizations and Clients, Ohio, Merrill.

Patton, Bobby 1973. Problem-Solving Group Interaction, New York, Harper.

Paulson, Steven 1974. "Causal Analysis of Interorganizational Relations: An Axiomatic Theory Revisited," Administrative Science Quarterly, 19, 3, September, 379-334.

Pelz, D. C. 1959. "Interaction and Attitudes Between Scientists and Auxiliary Staff," Administrative Science Quarterly, 4, 321-336.

Perrow, C. 1961. "The Analysis of Goals in Complex Organization," American Sociological Review, 26, 854-866. 
Pertin, J. 1973. "Emerging Perspectives About Organizational Planning and Development," Training and Development Journal, January, Vol. $27,8-17$.

Pettigrew, Andrew 1973. The Politics of Organizational Decision Making, London, Tavistock.

Presthus, Robert 1962. The Organizational Society, New York, Alfred A. Knopf.

Price, James 1972. Handbook of Organizational Measurement, Lexington, Massachusetts, Heath.

Pugh, D. S. et a1. 1969. "The Context of Organizational Structures," Administrative Science Quarterly, 14, 1, 91-114.

Pugh, D. S. et al. 1968. "Dimensions of Organization Structure," Administrative Science Quarter7y, 13, June, 65-105.

Pugh, D. S, et al. 1963, "Conceptual Scheme for Organizational Analysis," Administrative Science Quarterly, 18, December, 289-315.

Ratti, Rino V. 1974. "Organizational Resistance and Change," Social Services Review, 48, September, 369-383.

Rogers, Rolf E, and Marilyn McCreery-Spencer 1973. "Dilemma of Change and Future Organization," Sociological Focus, Spring, Vol. 6, No. 2, 42-60.

Rosenberg, M. 1968. The Logic of Survey Analysis, New York, Basic Books.

Rosengrer, William R. and Mark Lefton 1970. Organizations and Clients, Ohio, Merri11.

Rosengren, William R. 1968. "Organizational Age, Structure and Orientation Toward Clients," Social Forces, 47, September, 1-11.

Rosengren, W. R, 1967. "Structure, Policy and Style," Administrative Science Quarterly, 12, June, 140-164.

Rowe, Lloyd 1973. Organizational and Managerial Innovation, A Reader, Pacific Palisades, California, Goodyear.

Scott, W. 1961. "Organizational Theory," Journal of the Academy of Management, 4, April.

Shepard, H. A. and R. R. Black 1962. "Changing Behavior Through Cognitive Change," Human Organization (special issue), 88-96. 
Shu11, Fremont A. 1970. Organizational Decision Making, New York, McGraw-Hill.

Simon, Herbert 1965. "A Behavioral Model of Rational Choice," Quarterly Journal of Economics, February.

Simon, Herbert 1960. The New Science of Management Decision, New York, Harper.

Smith, H.W. 1975. Strateqies of Social Research: The Methodological Imagination, Englewood Cliffs, N. J., Prentice-HalT.

Soemardjan, S. 1957. "Bureaucratic Organization in a Time of Revolution," Administrative Science Quarterly, 2, 182-199.

Sofer, Cyrit 1964. "The Assessment of Organizational Change," The Journal of Management Studies, 1 , September.

Spencer, Paul and Cyril Sofer 1964. "Organizational Change and its Management," Journal of Management Studies, 1, March.

Starbuck, William 1965. "Organizational Growth and Development," in James G. March (ed.) Handbook of Organizations, Chicago, Rand McNal Ty, $457-533$.

Strihow, J. 1967. "Sharing the Defense Burden Among Western Allies," Review of Economics and Statistics, XXXXIX, November.

Sugarman, Barry 1967. "Some Inherent Sources of Change in Formal Organization," Social and Economic Administration, April.

Terreberry, S. 1968. "The Evolution of Organizational Environment," Administrative Science Quarterly, 12, March, 590-613.

Terrien, Frederick W. 1955 and Donald L. Mi17s 1958. "The Effect of Changing Size Upon the Internal Structure of Orqanization," American Sociological Review, 20, 11-13.

Thomas, Edwin J. 1957. "Effects of Facilitative Role Interdependence on Group Functioning," Human Relations, 10, 347-366.

Thompson, James D. 1967. Organization in Action, New York, McGraw-Hi11.

Thompson, James D. 1966. Approaches to Organizational Design, Pittsburgh, University of Pittsburgh Press.

Thompson, James D. 1962. "Organization and Output Transactions," American Journal of Sociology, 68, November, 308-324. 
Thompson, James D. and Arthur Tuden 1959. "Strategies and Processes of Organizational Decision," in Comparative Studies in Administration, Pittsburgh University Administration Center, University of Pittsburgh Press.

Thompson, James D. and William J. McEven 1958. "Organizational Goals and Environment: Goal Setting as an Interaction Process," American Sociological Review, 23, February, 23-31.

Thompson, James D. and Frederick L. Bates 1957. "Technology, Organization and Administration," Administrative Science Quarteriy, 2, December, 325-343.

Thompson, Victor 1965. "Bureaucracy and Innovation," Administrative Science Quarterly, $X$, June, 10-20.

Tsouderas, J. E. 1955. "Organizational Change in Terms of Series of Selected Variables," American Sociological Review, 29, 206-210.

Tuite, Matthew et a]. 1972. Interorganizational Decision Making, Chicago, Aldine.

Udy, S. 1962. "Administrative Rationality, Sociai Setting and Organizational Development," American Journal of Sociology, 68, 299-308.

Udy, S. 1959. "Bureaucracy and Rationality in Weber's Organization Theory," American Sociological Review, 24, December, 791-795.

Vroom, Victor 1973. "A New Look at Management Decision Making," Organizational Dynamics, Spring, Vol. 1(4), 66-80.

Waldo, Dwight 1961. "Organizational Theory: An Elephantine Problem," Public Administration Review, 21 , Autumn.

Walton, Richard E. and John M. Dutton 1969. "The Management of Interdepartmental Conflict," Administrative Science Quarterly, 14, March, 73-83.

Warren, Roland 1974. The Structure of Urban Reform, Lexington, Mass., Lexington Books.

Warren, Roland 1972, "The Concerting of Decision as a Variable in Organizational Interaction," in Matthew Tuite et al. Interorganizational Decision Making, Chicago, Aldine.

Warren, Roland 1966. Perspectives on the American Community, Chicago, Rand McNally.

Warren, Roland 1963. The Community in America, Chicago, Rand McNally. 
Wasserman, Paul and F. S. Silander 1964. Decision Making: An Annotated Bibliography, Ithaca, New York, Cornell University.

Wasserman, Paul 1958. Decision Making, New York, Corne11 University.

Weber, Max 1968. Economy and Society, translated by Ephraim et a1., New York, Bedminister Press.

Weber, Max 1962. Basic Concepts in Sociology, translated by H. P. Secher, New York.

Weber, Max 1956. Max Weber and German Politics, translated by J. P. Mayer, London, Faber and Faber, Ltd.

Weber, Max 1949. The Methodology of Social Sciences, translated by Edward Shils and Finch, Glencoe, Illinois, Free Press.

Weber, Max 1948. The Protestant Ethics and the Spirit of Capitalism, translated by Parsons, New York, Scribner.

Weber, Max 1947. The Theory of Social and Economic Organization, translated by Henderson and Parsons, Glencoe, Il7inois, Free Press.

Wetle, Terrie T. and Doug7as G. Montgomery 1976. Closing the Gaps: Strategies for Technical Assistance, Portland State University.

Whitel, Douglas 1969. Decision Theory, Chicago, Aldine.

Wilson, James Q. 1966. "Innovation in Organizations: Notes Toward a Theory," in James D. Thompson (ed.) Approaches to Organizational Design, Pittsburgh, University of Pittsburgh.

Woodward, Joan 1965. Industrial Organizational: Theory and Practice, London, Oxford University Press.

Zeldity, Morris and Terrence K. Hopkins 1961. "Laboratory Experiments with Organizations," in Amitai Etzioni Complex Organizations, New York, Holt, Rinehart and Winston. 
APPENDIX A

\section{QUESTIONNAIRE FOR COLLECTING DATA ON COMPLEXITY, FORMAL IZATION, CENTRALIZATION, AWARENESS OF INTERDEPENDENCY \\ AND DECISION TO PARTICIPATE}

\section{INTRODUCTION}

The purpose of this study is to gather information regarding the work of agencies which provide services to the older adults in your community. Your responses will be confidential and all results will be reported in the aggregate so as not to be identifiable to any one agency or individual. We very much appreciate your willingness to cooperate with us and agreeing to do this interview. We will send you a report of information gathered for your comments and use.

First, let me ask you a few questions about you and your agency.

I. Characteristics of Respondent

A. Agency

B. Age of Agency

c. Purpose

D. Respondent's Name

E. Age

F. Your Position

G. 1. How long have you been personally involved with providing services to the elderly? 
2. Which $\operatorname{program}(s)$ ?

H. Are you a volunteer?

II. Organizational Variables

A. Complexity

1. How many people are employed by your organization?

2. How many job positions are there between the chief administrator and the employees directly working on providing services to the elderly?

B. Centralization

1. In examining how your agency works, how frequently does the staff participate in client service decisions?

Never

Seldom

Sometimes

often

2. In examining how your agency works, how frequentiy does the staff participate in new program decisions? Never

Seldom

Sometimes

Often

C. Formalization

1. In examining how your agency works, how frequently does 
everyone have a specific job to do?

Never

Seldom

Sometimes

Often

2. In examining how your agency works, how frequentiy is going through channels stressed?

Never

Seldom

Somet imes

Often

D. Awareness of Interdependency

In each of the items below please check the one statement which represents your choice.

1. Some organizations need more support from the general community than others. Check the statement below which comes closest to describing the situation of your agency. It could never accomplish anything without strong community support Community support is important to it but not absolutely essential for everything it does Community support is desirable but not really a major factor in its success It does not realiy matter whether the community supports the program or not 
It hopes to accomplish its goals despite opposition from a major element of the community

2. Which one of the following statements comes closest to describing the best possible way of interrelating the programs and services specifically for the aged in this community? Would you say that most programs for older adults. . .

Should be as separate and autonomous as possible from one another

Should be organized to allow easy consultation between them as the need arises

Should be organized with the provision for regular and frequent meetings, information exchange, liaison regarding $c l i e n t s$ on a routine basis Should be centrally coordinated to facilitate the working out of common priorities, service approaches and target group strategies

Should be centrally administered by a single agency in hopes of eliminating overlap and duplication of services among agencies

E. Decision to Participate

1. What is the nature and frequency of your agency's involvement with the coordinating agency?

2. In the past month, how many client referrals has your organization made to other agencies? 
3. In the past month, how many client referrals were made to you from other agencies?

4. In the past month, how many client referrals lias your organization made to the coordinating agency?

5. How many have they made to you?

6 . In the past month, how many times have you provided information to the coordinating agency?

7. How many times have they provided information to you?

8. In the past month, how many times have you provided information to other agencies?

Note: This questionnaire is part of a larger questionnaire done by the research team at the Institute on Aging, Portland State University. For complete details, refer to AAA-TA (1976). 


\section{APPENDIX B}

FRAMEWORK FOR CASE STUDIES INTERVIEWS

1. Who were the key actors?

Board members

Director

Staff

Clients

Questions were asked about agency personnel who participated in making the decisions. An attempt was made to identify the key actors of the decision making process. The questions were asked to find out if the key actors were board members, directors, staff, clients or all of them who in some way participated in the decision making process.

2. Responsibilities for the decisions.

Who led?

Who first learned?

Who was consulted?

Within the organization who was in favor of the decision and who was against it? What were the inside as well as the outside influences in making the decisions?

What were the timing and degrees of events?

Questions were asked to identify the responsibilities of various key actors for the decisions made. Who initiated the move for making 
the decision? Who first learned about the situation demanding a decision? Who was consulted before the decision was made? Did the key actors consider the forces within the organization which were in favor of the decision and which were against it? What were the external and internal influences which impacted the decision? Questions were asked about the timing and degrees of events which led to a particular decision.

3. What were the motivations in making the decisions? Was budget a motivation? Was power a motivation? Were clients a motivating influence?

Questions were asked about the motivations in making particular decisions. Was the decision made to gain more resources or was it made to increase the agency's domain of influence, or was it made to gain more clients?

4. What were the constraints in making decisions? What options were considered in making decisions?

Questions were asked about the nature and scope of corstraints experienced by decision makers in making the decisions, and whether various options were considered by decision makers before the final decision was made.

5. What kinds of agreements or promises were made to other organizations while making the decisions? 
Questions were asked about the agreements or promises made by the decision makers to other organizations while making the decisions.

6. Was the decision made under crisis?

Was the decision made under conflicts?

Was the decision an innovation; was it expansion; or was it substitution?

Questions were asked about the types of decisions. Was it a crisis decision, a conflict decision, an innovative decision, or was it an expansion or a substitution? 